\title{
Tank 19F Folding Crawler Final Evaluation, Rev. 0
}

by

T. Nance

TECEIVEO

NOV 032000

Westinghouse Savannah River Company

Savannah River Site

Aiken, South Carolina 29808

This paper was prepared in connection with work done under the above contract number with the U.S. Department of Energy. By acceptance of this paper, the publisher and/or recipient acknowledges the U. S. Government's right to retain a nonexclusive, royalty-free license in and to any copyright covering this paper, along with the right to reproduce and to authorize others to reproduce all or part of the copyrighted paper. 


\section{DISCLAIMER}

This report was prepared as an account of work sponsored by an agency of the United States Government. Neither the United States Government nor any agency thereof, nor any of their employees, makes any warranty, express or implied, or assumes any legal liability or responsibility for the accuracy, completeness, or usefulness of any information, apparatus, product or process disclosed, or represents that its use would not infringe privately owned rights. Reference herein to any specific commercial product, process or service by trade name, trademark, manufacturer, or otherwise does not necessarily constitute or imply its endorsement, recommendation, or favoring by the United States Government or any agency thereof. The views and opinions of authors expressed herein do not necessarily state or reflect those of the United States Government or any agency thereof.

This report has been reproduced directly from the best available copy.

Available for sale to the public, in paper, from: U.S. Department of Commerce, National Technical Information Service, 5285 Port Royal Road, Springfield, VA 22161

phone: (800) 553-6847

fax: (703) 605-6900

email: orders@ntis.fedworld.gov

online ordering: http://www.ntis.gov/ordering.htm

Available electronically at http://www.doe.gov/bridge

Available for a processing fee to U.S. Department of Energy and its contractors, in paper, from: U.S. Department of Energy, Office of Scientific and Technical Information, P.O. Box 62, Oak Ridge, TN 37831-0062

phone: (865)576-8401

fax: (865)576-5728

email: reports@adonis.osti.gov 


\section{DISCLAIMER}

\section{Portions of this document may be illegible in electronic image products. Images are produced from the best available original document.}


WSRC-TR-2000-00301

\section{Tank 19F Folding Crawler Final Evaluation, Rev. 0}

Westinghouse Savannah River Company

Savannah River-Site

Aiken, South Carolina 29808 
APPROVAL SHEET

Allure Dilinea

Level 3 Manager, EES Department
DECEIVED NOV 032000

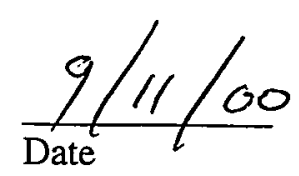
OS TI

Tank 19F Folding Crawler Development Team
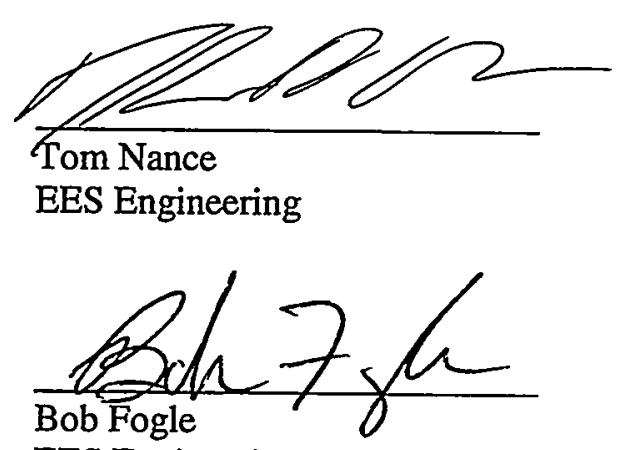

EES Engineering

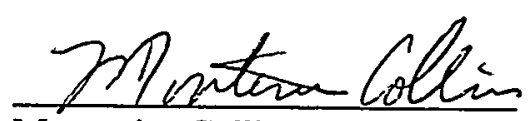

Montenius Collins

EES Engineering

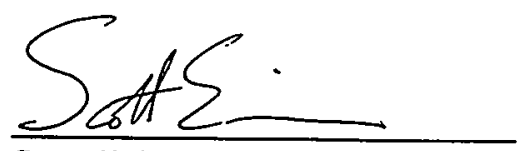

Scott Erickson

EES Engineering

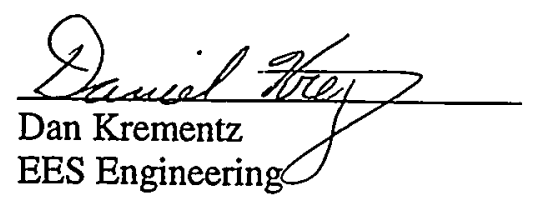

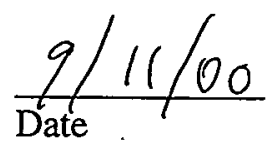
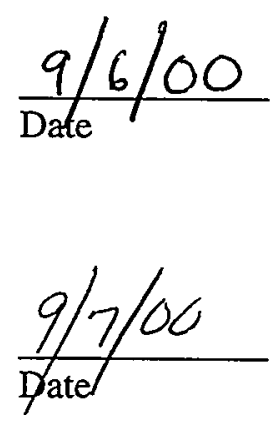

$\frac{8-31-\infty}{\text { Date }}$

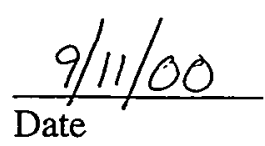




\section{TABLE OF CONTENTS}

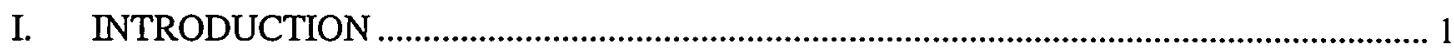

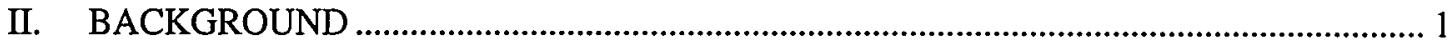

III. FYOO CRAWLER SYSTEM DEVELOPMENT......................................................... 8

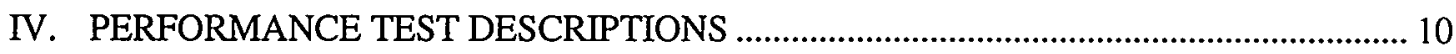

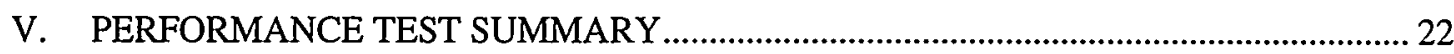

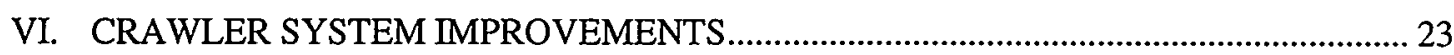

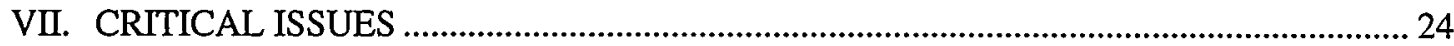

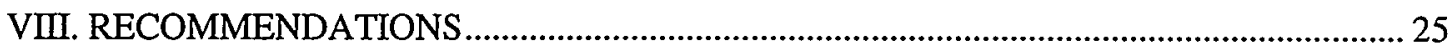

IX. REQUIREMENTS FOR FIELD DEPLOYMENT AND OPERATION ............................ 25

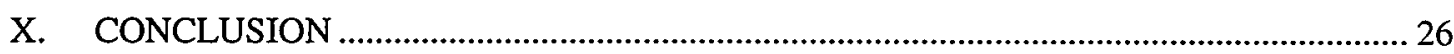

APPENDIX A - AKRON BRASS DATA SHEETS

APPENDIX B - INUKTUN CRAWLER DATA SHEET 


\section{LIST OF FIGURES}

Figure 1. AKron Brass Gemini ElECtric WATER MONITOR 2

FIGURE 2. SCHEMATIC SHOWING TANK 19F RISER POSITIONS AND ASSOCIATED TANK CLOSURE EQUIPMENT .

FIGURE 3. INUKTUN MINITRACS 4

FIGURE 4. ILLUSTRATION SHOWING FOLDED/UNFOLDED CRAWLER FRAME AND MOUNTED WATER MONITOR 6

FIGURE 5. FOLDING CRAWLER DEPLOYMENT AND RETRIEVAL STEPS. 7

FIGURE 6. LAB DEMONSTRATION OF FOLDING CRAWLER AND WATER MONITOR. 8

FIGURE 7. TANK 19F FOLDING CRAWLER OPERATING IN SIMULATED SLUDGE IN TEST BED ....... 11

FIGURE 8. CRAWLER DEPLOYMENT THROUGH MOCKUP RISER ............................................. 14

FIGURE 9. CRAWLER IN FOLDED POSITION BEING LOWERED INTO MOCKUP TANK ..................... 15

FIGURE 10. CRAWLER CHASSIS EXPANDED ON MOCKUP TANK FLOOR ....................................... 15

FIGURE 11. WATER MONITOR/NOZZLE LOWERED THROUGH MOCKUP RISER................................ 16

FIGURE 12. WATER MONITOR/NOZZLE LOWERED INTO MOCKUP TANK ..................................... 16

FIGURE 13. WATER MONITOR/NOZZLE COUPLING OPERATION WITH CRAWLER CHASSIS ............. 17

FIGURE 14. CRAWLER AND WATER MONITOR READY FOR DEPLOYMENT IN MOCKUP TANK ....... 17

FIGURE 15. CRAWLER MANEUVERING AND DRAGGING WATER HOSE IN MOCKUP TANK.............. 18

FIGURE 16. CRAWLER SPRAYING WHILE TRAVERSING MOCKUP TANK ........................................ 18

FIGURE 17. TANK HEEL AND CRAWLER READY FOR MATERIAL REMOVAL TASKS ........................ 19

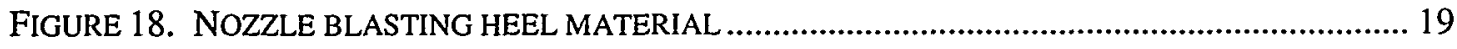

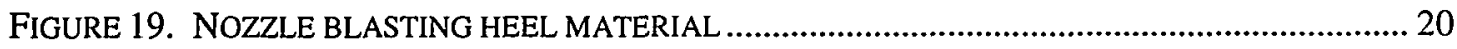

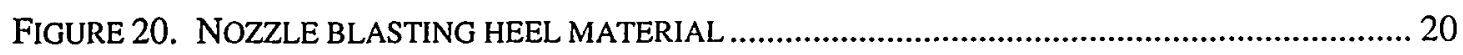

FigURE 21. HeEl AFTER MATERIAL has BeEN DISPLACED BY NOZZLE .................................... 21

FIGURE 22. CRAWLER STABILITY TESTED WHILE SPRAYING ON AN INCLINED SURFACE.............. 21

FIGURE 23. CRAWLER STABILITY TESTED WHILE SPRAYING IN CLOSE PROXIMITY TO WALL...... 22 


\section{INTRODUCTION}

The Department of Energy (DOE) is committed to removing millions of gallons of high-level radioactive waste from 51 underground waste storage tanks at the Savannah River Site (SRS). The primary radioactive waste constituents are strontium, plutonium, and cesium. It is recognized that the continued storage of this waste is a risk to the public, workers, and the environment. SRS was the first site in the DOE complex to have emptied and operationally closed a high-level radioactive waste tank. The task of emptying and closing the rest of the tanks will be completed by FY28.

The tanks were built underground to provide shielding from the intense radiation fields emitted by the highly radioactive waste. Operations, maintenance, and waste handling are done under strict radiological controls to avoid direct personnel exposure and prevent the spread of contamination. The waste from each tank will be transferred to a waste pretreatment facility and then on to the Defense Waste Processing Facility where it will be vitrified and poured into stainless steel containers. The removal of the waste from the tanks involves installation of mechanical agitators or mixers and pumping systems on each tank to re-dissolve the precipitated waste salts and suspend insoluble waste solids. Large amounts of corrosion-inhibited water are added to the tank. Advanced mixers suspend the insoluble sludge or dissolve the salt cake that has formed. The pumping system will remove the waste slurry from the tank. After waste removal, the interior of each tank is washed with water. Each tank is isolated physically by capping and sealing all pipes as well as cutting all electrical connections. Finally, the tank is filled with grout.

The next tank scheduled for decommissioning is Tank 19F located in F-area. Based upon decommissioning guidelines, the goal is to leave no more than 1000 gallons of material in the tank upon closure. A hardened mass of solid waste material, known as a heel, was observed lying at the bottom of Tank $19 \mathrm{~F}$ during a previous inspection. The heel was described as an hourglass shaped mound located in the center of the tank. It is presently not known whether this heel still exists. However, the heel composition could consist of more than a 1000 gallons of material and thus would necessitate reparation. The agitators/mixers may have little effect upon this mass. A spray system comprised of a high pressure, adjustable water nozzle was used in previous tank closure processes. It is felt that this nozzle may be able to break up the tank heel if operated at close range. Once the heel is broken up, the mixers and pumps will be effective in removing the material from the tank. In planning for tank heel mitigation, the High Level Waste (HLW) Division requested assistance from the Savannah River Technology Center's (SRTC) Engineered Equipment and Systems Department (EES). The request called for EES to design, fabricate, assemble, and test a remote-controlled crawler that could carry a high pressure, water nozzle in Tank 19F.

\section{BACKGROUND}

In FY98, Technical Assistance Request (TAR) \# HLE-TTR-1998-031, rev. 0, authorized EES to design, fabricate, assemble and test a remotely controlled, tracked, mobile transport platform to interface with a HLW tank spray system. The spray system consisted of an Akron Brass Gemini Electric Water Monitor, model type Pyrolite 3478, similar to the one shown in Figure 1. This spray tool weighs 67 pounds, is 20 " tall and 13" wide. The nozzle for the water monitor is the Akromatics 5119 rated at 100 -gallons per minute (gpm) at 100-pounds per square inch (psi). The vendor data sheets for this equipment can be found in Appendix A. EES engineers were asked to test and demonstrate the crawler and spray system and issue a report to HLW summarizing test results and conclusions regarding the ability of the system to assist in tank closure activities. 


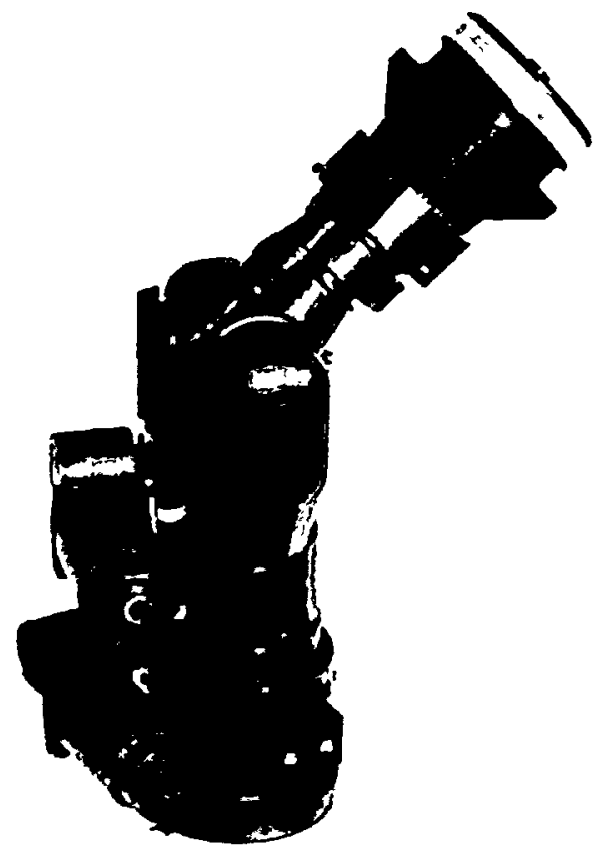

Figure 1. Akron Brass Gemini Electric Water Monitor

Tank $19 \mathrm{~F}$ is $85^{\prime}$ in diameter and $35^{\prime}$ high. The best available estimates of the nature of the material currently in Tank $19 \mathrm{~F}$ are as follows:

1. 13,000 gallons of sludge

2. 7,000 gallons of zeolite

3. 13,000 gallons of salt

4. 254,000 gallons of water

According to detailed tank chemistry reports based on recently recovered dip samples and other pertinent tank content information, the contents of Tank $19 \mathrm{~F}$ consist primarily of a high $\mathrm{pH}$ (10-13) combination of salt solution supernate and sludge. The primary constituents of the tank's contents are sodium aluminum nitrate, aluminum nitrate, sodium hydroxide, aluminum hydroxide, and various sludge components such as zeolite and gibbsite. The temperature in the tank was measured to be approximately $100^{\circ} \mathrm{F}$. The major radioactive elements in the tank include cesium 137 and strontium 90 .

Access to the interior of the tank is achieved through fixed structures, referred to as risers, located in a number of tank top positions. These round openings are typically less than 2' in diameter and approximately 6 ' long. Tank closure equipment including mixers and pumps are installed in many of the available riser locations as shown in Figure 2. Other risers contain mounted instrumentation to monitor tank conditions. This equipment and instrumentation take up riser space and introduce a number of obstructions in the tank interior and on the tank floor. Miscellaneous obstacles such as lifting plates, reel tapes, and other debris might also be scattered across the tank floor. 


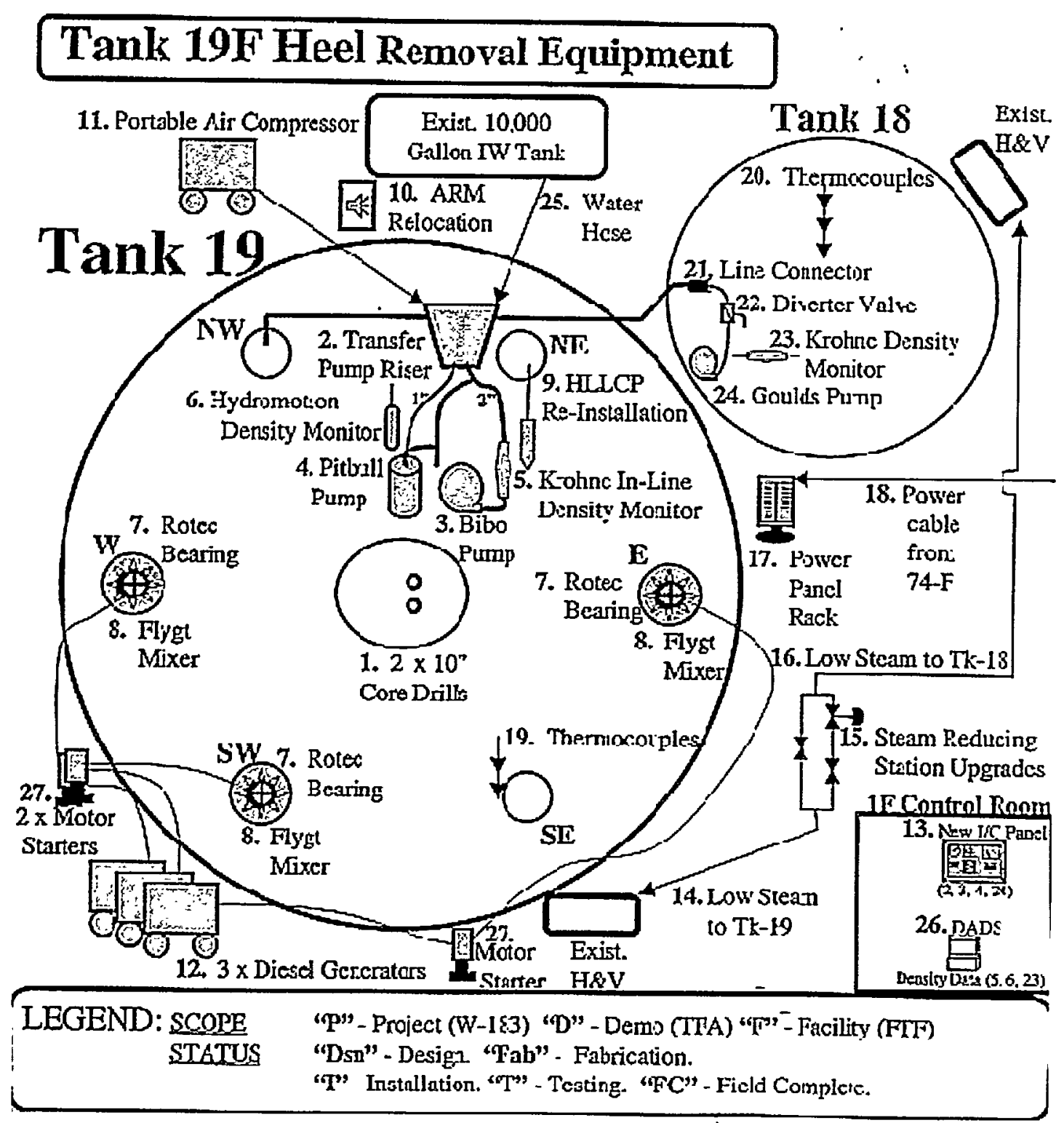

Figure 2. Schematic showing Tank 19F riser positions and associated tank closure equipment 
TAR \# HLE-TTR-1998-31, revision 0, provided the design criteria for the tank crawler. The criteria are as follows:

1. Carry a payload of approximately $100 \mathrm{lbs}$.

2. Be compatible with tank chemistry and radiation levels.

3. Fit through a nominal 23 " diameter riser.

4. Be of minimal cost.

5. Be able to crawl over $1 / 2$ inch high lifting plates.

6. Be able to crawl through sludge and supernate.

7. Be waterproof.

8. Have a 3-month design life in the waste tank interior.

9. Be able to remotely couple with the water monitor from within the tank.

Criteria 1 - 4 represented the most challenging design issues. EES engineers identified a lowcost, low profile, off-the-shelf set of crawler tracks manufactured by Inuktun Services Limited. Inuktun specializes in the development of small, remotely operated vehicles and devices. EES has successfully used Inuktun's crawler tracks or MiniTracs systems in a number of site applications. The stainless steel version of the MiniTracs shown in Figure 3 met the design requirements. The tracks are compact as well as strong and utilize a deep-lug tread design. A set of 4 Minitracs can support 100 pounds. The complete track specification can be found in Appendix B.

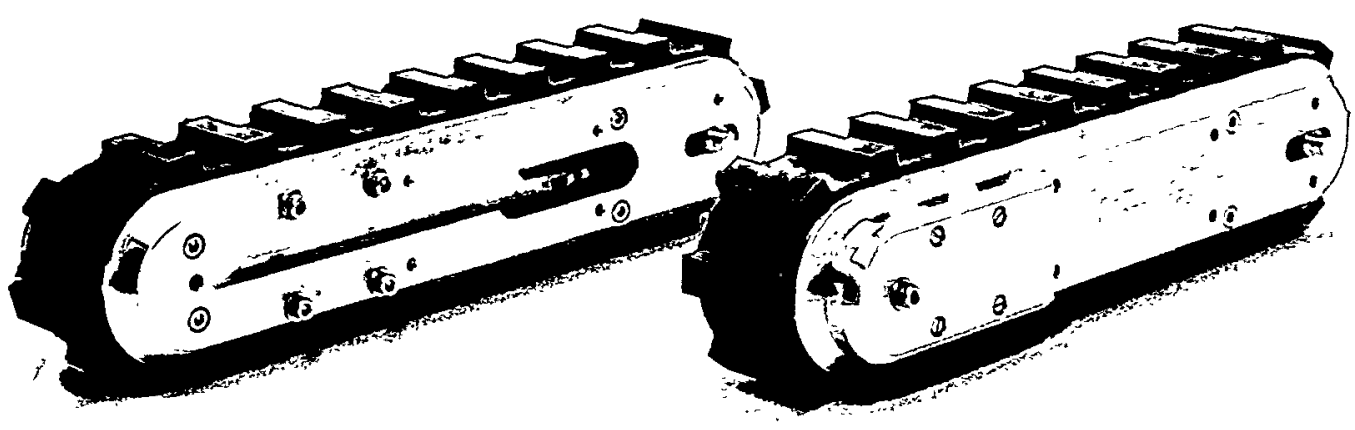

Figure 3. Inuktun Minitracs

It was necessary to use equipment that could withstand the tank's corrosive chemistry and radiation levels. EES requested that the Materials Technology Section (MTS) perform an analysis of the track's components. A number of items were incompatible with the tank's contents as reported in the MTS document \#SRT-MTS-98-4033, "Review of Inuktun Minitrac Module/Tank 19F Compatibility (U)". The vendor was able to replace incompatible stock components with others that were more suitable to Tank 19F conditions. A set of 4 stainless steel crawler tracks with deep-lug belts was purchased and received. 
The crawler had to be strong enough to support the size and weight of the water monitor. At the same time, the crawler needed to be small enough to pass through one of the tank's 23 " diameter risers. EES engineers designed a crawler with a collapsible frame, illustrated in Figure 4. The water monitor is mounted to an adapter plate that fits onto dowel pins located on top of the crawler. Figure 5 illustrates the steps involved in deploying and retrieving the crawler/water monitor system into and out of the tank. The folded crawler is lowered into the tank through the riser. After the chassis is landed and expanded, the crawler is positioned under the entry riser. The spray system is lowered separately through the same riser and remotely coupled to the crawler. The crawler and spray system are tethered and controlled by personnel at the control station located a safe distance away from the tank. The folding crawler frame or chassis, an adapter plate for the water monitor, and remote control console for the water monitor were designed, fabricated, and assembled in FY98. The folding crawler and water monitor system shown in Figure 6 were demonstrated to HLW personnel in the robotics laboratory in SRTC.

Some concern was expressed about the crawler's ability to drag its own cable and the cable and hose of the water monitor. The crawler vendor developed a sludge tread design using the deep-lug tread belt and steel cleats. It was thought that the steel cleat design would provide better traction in the thick sludge at the bottom of the tank. A set of these modified treads was purchased. However, the steel cleats were very sharp and testing revealed that there was a possibility of severing the control cables and water hose. Meanwhile, the vendor supplied documentation of pull tests performed using the stock deep-lug belt under a number of conditions. Although the data was informative, it did not fit the conditions found in a waste tank. Further tests would be required using simulant sludge to gauge the crawler's traction capability.

Additionally, there was some concern that the force produced by the spraying water monitor could effect the stability of the crawler. These concerns would be exacerbated if the crawler operated on an incline. Stability calculations were performed on the crawler. These calculations, found in EES Job Folder \#22649, indicated that the crawler would maintain stability under normal operating conditions. Before traction and stability testing could begin, funds for FY98 were depleted.

In FY99, Work Authorization Document (WAD) funding was obtained to make changes to the crawler chassis including the addition of a center support, a spring assisted expansion bar, and a safety cable attachment point. Also, this funding supported the first crawler and water monitor field test, referred to as the "parking lot test". The purpose of this test was to determine if there were any traction or stability problems caused by operating the water monitor under load as the crawler attempted a number of maneuvers.

In the "parking lot test", the crawler was able to pull both control cables and 100' of 2-1/2" fire hose. The crawler moved in straight and circular paths. It also traveled over an 18 " high mound of compacted dirt. The crawler could not skid-steer in the dirt and was observed to bog down as well. The drive system's fuses open-circuited during this phase of the testing. The stability of the crawler platform was tested by discharging water through the water monitor as it panned in both directions and tilted. The crawler remained stable during water monitor operation.

The "parking lot test" demonstrated the stability of the crawler platform under load. It also established that the motorized crawler tracks lacked sufficient power to perform some required maneuvers. A second set of tracks with more powerful motors was purchased and received. FY99 funding was depleted before the new tracks could be tested on the chassis. 

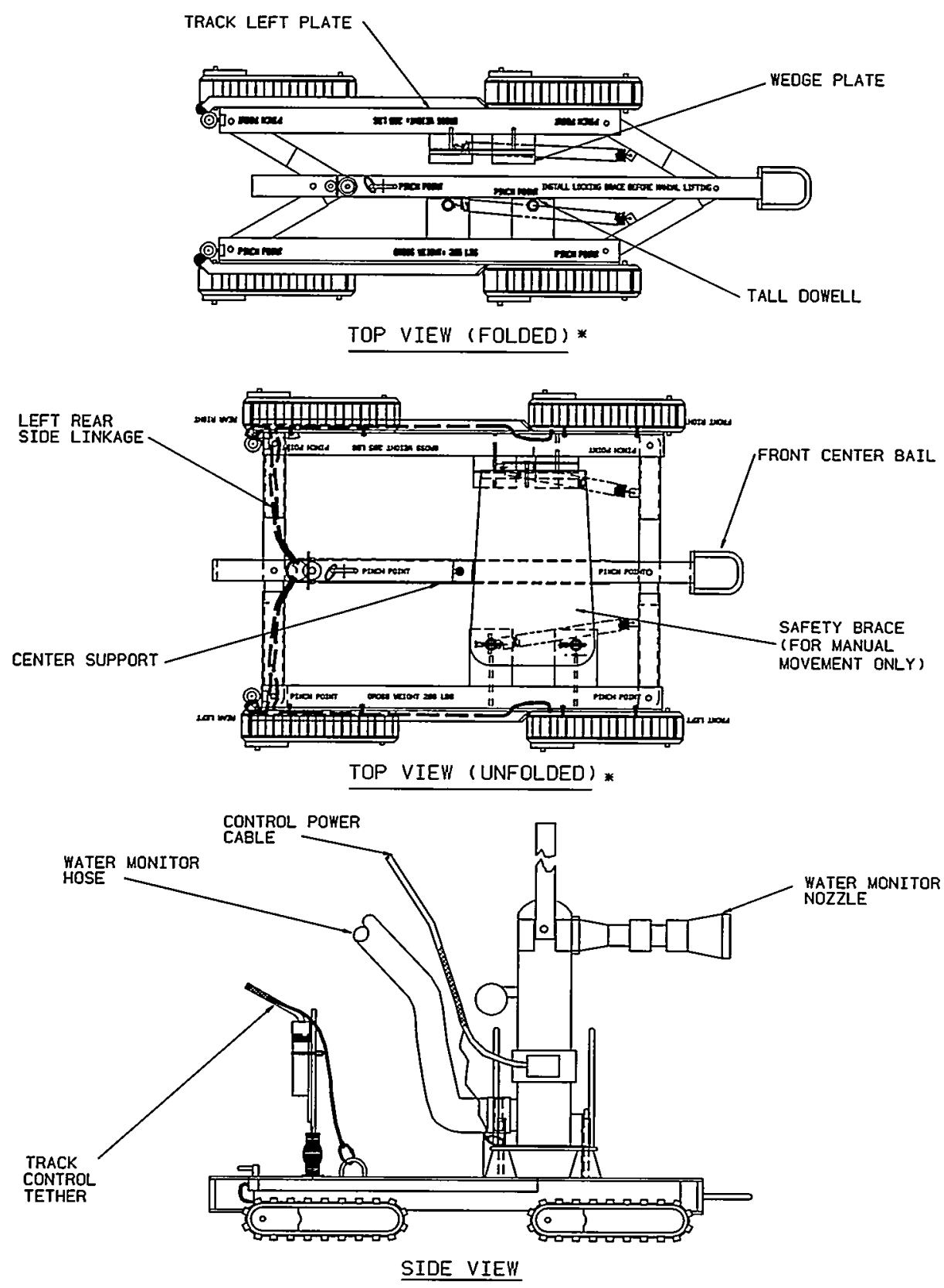

Figure 4. Illustration showing folded/unfolded crawler frame and mounted water monitor 

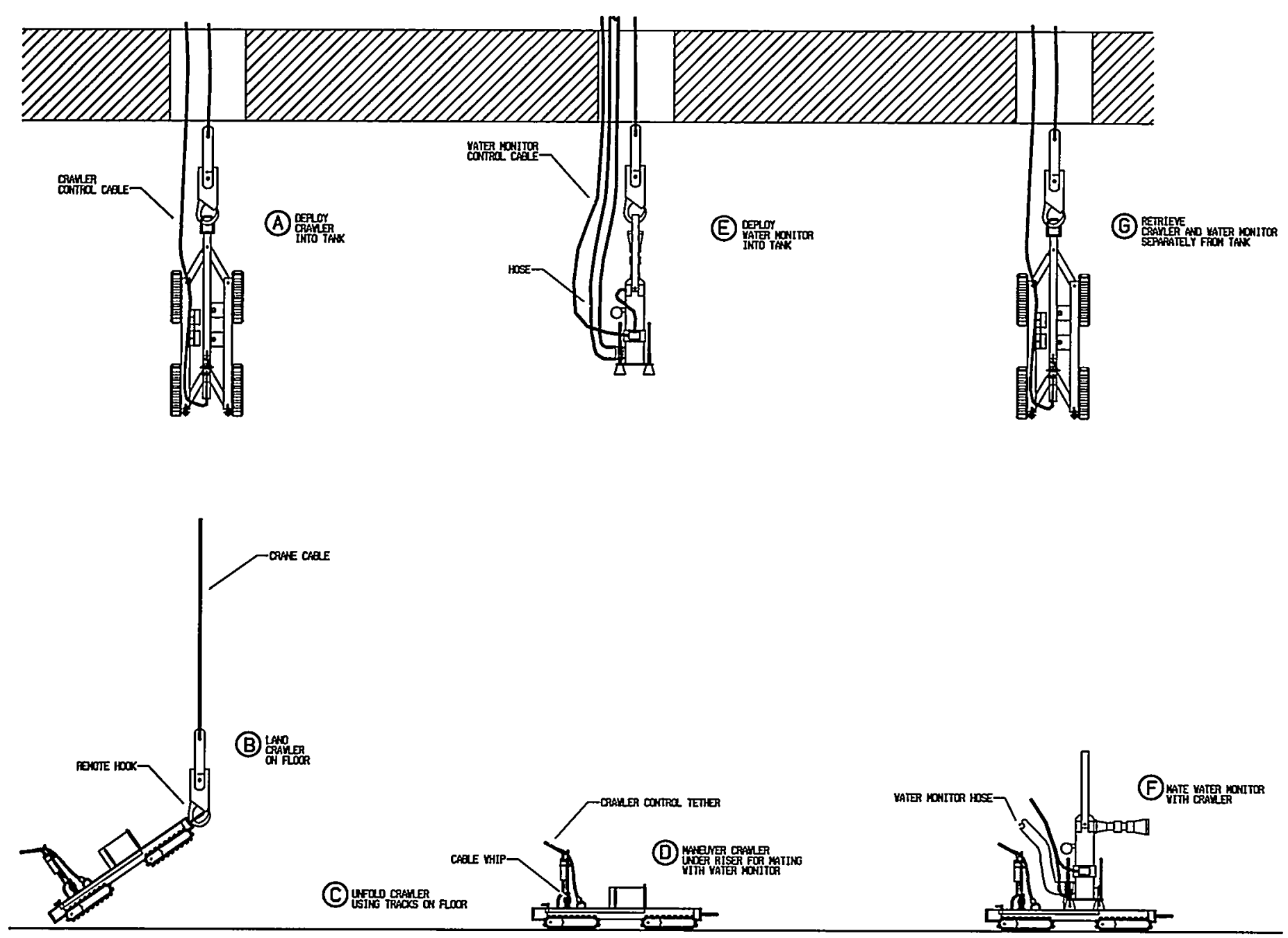

Figure 5. Folding crawler deployment and retrieval steps 


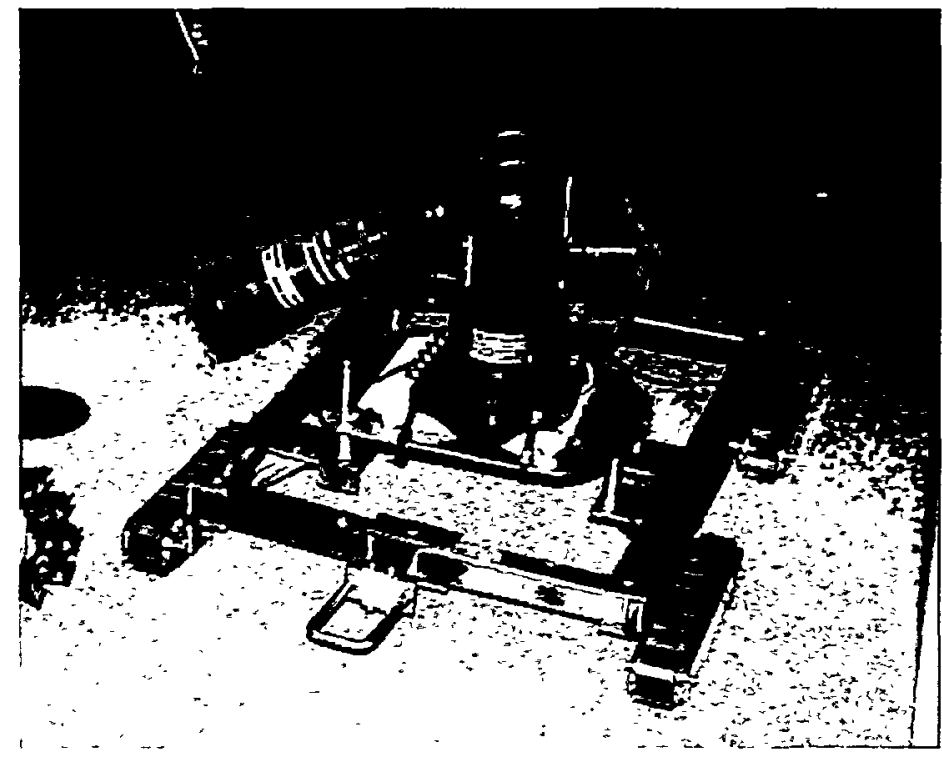

Figure 6. Lab demonstration of folding crawler and water monitor

\section{FYO0 CRAWLER SYSTEM DEVELOPMENT}

In FY00, the crawler and water monitor system became known as the Tank 19F Folding Crawler System. TAR \# HLE-TTR-1998-031, revision 1, was issued and additional funding was made available to complete the evaluation of the crawler and water monitor through a series of 4 performance tests. Prior to the performance tests, EES obtained a remote hook for deployment and retrieval of the crawler and water monitor and made significant improvements to the crawler's folding chassis and the water monitor's adapter plate. These changes were made to improve the unfolding of the crawler frame, improve the landing of the crawler, improve mating of the crawler and the water monitor, improve retrieval of the water monitor, and ready the system for deployment. The mechanical and electrical changes to the crawler chassis included:

1. Removing the rear bail.

2. Welding a bail and plate to the center support.

3. Adding strain relief attachment points.

4. Adding conduit on the track mounting plates to protect motor cables.

5. Extending one dowel on the frame to improve the water monitor coupling process.

6. Mounting springs to assist in expanding the frame.

7. Adding strain-relief to the crawler's control cable.

8. Adding strain-relief to the water monitor's control cable.

9. Mounting the crawler's control cable connector to a spring-loaded whip.

10. Routing motor cables within the crawler frame.

11. Installing more powerful motorized tracks on the frame.

12. Replacing the steel-cleat treads with the standard deep-lug treads.

13. Fabricating a safety brace to install when manually moving the crawler without the water monitor attached. 
The changes made to the water monitor's adapter plate included:

1. Mounting a bail.

2. Adding strain-relief attachment points.

3. Adding guide rails.

The original process for deploying the folded crawler frame required the frame to be lowered by the rear bail with a remote hook and two additional fixed aircraft cables. The crawler would be lowered into the tank and two attached cables would be used to allow the frame to expand while suspended. After landing and removal of the remote hook, those cables remained on the crawler during operations within the tank. However, this increased the potential for catching on obstructions within the tank or the crawler itself. The original deployment concept also resulted in a complicated crawler deployment with the crawler landing on its front bail. The deployment and crawler frame expansion process was changed to allow the crawler to be deployed by simply landing on the crawler's rear tracks thereby negating the need for additional cables.

The new crawler deployment process involves attaching a remote hook to the front bail. The crawler remains folded until it lands on the tank floor. The rear bail was removed to allow the crawler to land on its rear tracks. The rear tracks assist with the landing by driving backward to lower the crawler slowly to the floor. After disengaging from the remote hook, the crawler frame is unfolded and expanded due to the movement of the crawler tracks. The frame also has springs that aid the tracks in expanding the frame.

One of the mating dowels on the crawler frame was lengthened. This longer dowel allows the operator to engage one of the dowels with the suspended water monitor during coupling and move the crawler underneath to align with the second dowel receptacle. Once the second dowel is aligned, the water monitor can be successfully lowered onto the crawler.

A lifting bail was added to the water monitor to aid in deployment. The bail has a crossbar to allow the disengagement of the remote hook. The water monitor's adapter plate also had guide rails added to ease retrieval through the riser if needed. An attachment point for the water monitor's control cable strain relief was added to the adapter plate.

More powerful tracks were mounted on the crawler frame to improve its skid-steer capability. The paddle tread design was removed and the deep-lug tread was installed. The track cables were routed through the frame for protection. Conduit was added to the outside of the track mounting plates to complete the cable protection. An attachment point for the crawler control cable strain relief was added to the center support of the chassis. Finally, a safety brace was fabricated to permit safe handling of the crawler when being handled manually. The safety brace immobilized the crawler frame in its expanded configuration eliminating possible pinch points.

Dynamic drop calculations were performed by the Structural Mechanics group to verify that the water monitor/crawler assembly would not perforate the Tank 19 liner and base slab if accidentally dropped during deployment. According to Calculation Report \#T-CLC-F-00167, the crawler cannot perforate the tank liner and base slab if dropped from the height at which it will enter the tank.

An Akromatics motorized nozzle, model number 5068, rated at 250-1250 gpm was purchased. It was felt that a motorized nozzle was needed to provide the ability to remotely 
change the spray pattern. The motorized nozzle was installed on the water monitor in place of the $100 \mathrm{gpm}$ nozzle.

\section{PERFORMANCE TEST DESCRIPTIONS}

The performance tests were held either in the 723-A Highbay or at the TNX Full Tank Test Facility. The Highbay is a 80 ' high tower-like structure with a test platform at 42 ' positioned to simulate the riser top to tank floor dimension. A bridge crane is located at the top of the Highbay facility. The TNX Full Tank Test Facility is a carbon-steel tank, 85' in diameter and 10' deep, with a capacity of 250,000 gallons. The tank has no top to maximize operational and testing flexibility. A support structure is built adjacent to the tank for testing equipment up to $45^{\prime}$ tall. The tank has been primarily used for development and verification testing of long-shaft centrifugal pumps. It has also been used to test deployment and operation of waste removal devices such as water spray systems and mechanical crawlers. The Full Tank Test Facility was an ideal location to test the Tank19F Folding Crawler System.

The performance tests were conducted in a logical order based on actual deployment process steps. Four tests were performed to acquire information on deployment and operational concerns with the crawler and water monitor. These concerns were:

- Clearance through the riser.

- Crawler traction in simulated sludge.

- Remote coupling and de-coupling of the crawler and water monitor.

- Crawler operation in a full-scale tank with simulant sludge.

The riser clearance or fit test was conducted to verify the crawler and water monitor could fit through a mockup of the preferred riser on Tank 19F. The crawler traction test was performed to gauge crawler traction in simulant tank sludge as well as determine limitations based on sludge depths. A deployment test was completed to assess crawler and water monitor coupling and decoupling. Finally, a full-scale tank mockup test using sludge simulant was executed to evaluate important operational dynamics such as the deployment of the crawler and water monitor, and the ability to pull the control cables and a hose across the tank floor. In addition, the ability of the system to move material on the tank floor was tested and demonstrated.

All development and testing work was performed in accordance with SRTC's Conduct of Research and Development Manual. Load tests and weld inspections were performed on the lifting bails of the crawler as described in NDE Inspection Summary \#TSD-NDE-2000-0169. A Safety Manual Item 51 inspection was conducted on the system before the testing began. Preparations for each test included a Job Hazards Analysis (JHA), a written test plan (see EES Job Folder \#22649), a work clearance permit, and a pre-job briefing. HLW maintenance personnel coordinated test support work, scheduled the tests, reviewed the test plans and monitored the tests. TNX personnel supplied operational support. Construction supplied the necessary laborers, crane operators, and riggers. EES personnel wrote the tests plans, conducted the pre-job briefings and operated the crawler system. Hazardous energy lockout/tagout procedures were enforced during all crane lifting and equipment setting operations.

\section{Riser Fit Test}

The Riser Fit Test was conducted at the TNX Full Tank Test Facility. The objective of the test was to verify that the folding crawler chassis and water monitor fit through a tank riser. 
There are a limited number of risers on the tank top. HLW initially planned to deploy the crawler through the northeast (NE) riser; the southeast (SE) riser was the secondary choice. As shown in Figure 2, equipment including Flygt mixers, pumps, and instrumentation are mounted in the Tank 19F NE and SE risers during closure activities. The Pitbull and Bibo pumps are located near the bottom of the tank directly beneath the NE riser. The pump support structure partially blocks the riser opening causing limited access. This test would determine if the crawler and water monitor could be inserted through the NE riser. HLW personnel witnessed attempts to insert the crawler and water monitor into a mockup of the Tank 19F NE riser. The crawler passed through the riser, but the water monitor could not. As a result of this test, it was decided that the SE riser would be the entry point for the crawler system. Unlike the NE riser, the SE riser contains tank instrumentation that can be temporarily removed allowing total riser access for crawler and water monitor insertion. Also, deploying through the SE riser would enable the crawler to efficiently and systematically travel across the tank diameter toward the pumps located beneath the NE riser. The crawler could then engage the mound in the center of the tank and blast it toward the pumps.

\section{Traction Test}

The Traction Test was conducted at the TNX Full Tank Test Facility. The objectives of the test were to determine the:

- Effects of sludge buildup on the crawler tracks.

- Maximum sludge operation depth of the crawler.

- Effects of sludge on the crawler's ability to drag control cables and the water monitor's hose.

- Effects on crawler traction due to the slippery nature of sludge.

An $8^{\prime}$ by $16^{\prime}$ by $1^{\prime}$ 'test bed, see Figure 7, was built in a portion of the TNX Full Tank. Laborers loaded dry kaolin into the test bed, added water, and mixed to achieve a thick consistency of simulant. A ThermoGravimetric Analysis was conducted by MTS on samples of the hydrated kaolin mixture measured the moisture content between $30-40 \%$.

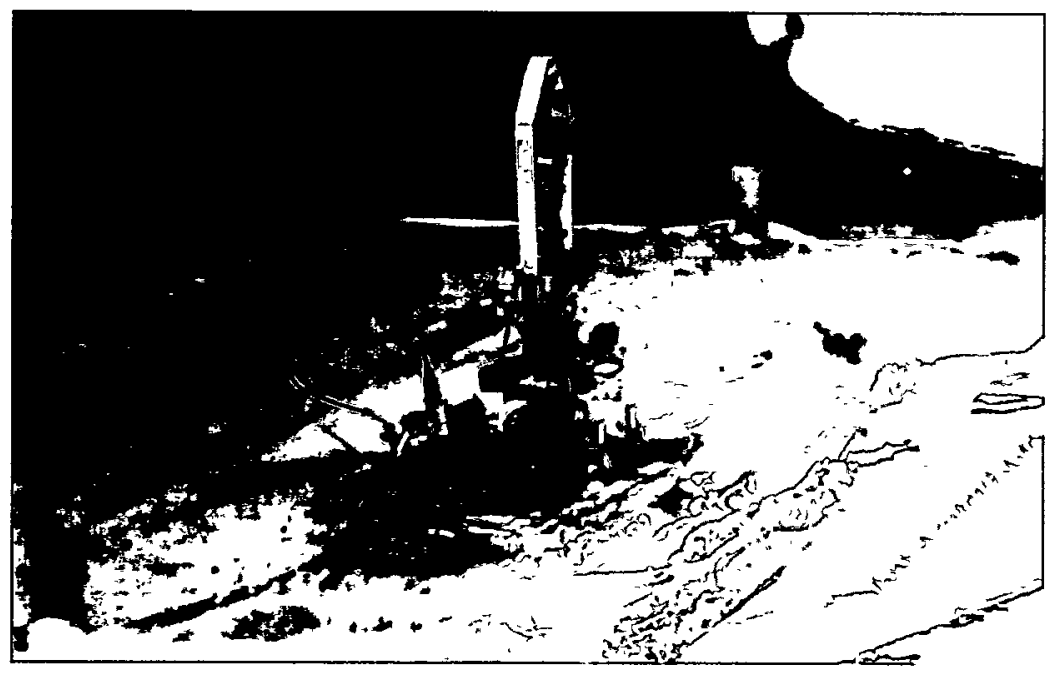

Figure 7. Tank 19F folding crawler operating in simulated sludge in test bed 
During traction testing, the tread never slipped off the crawler tracks, even when performing tight turns. A large buildup of simulant on the sides of the crawler tracks did not hinder maneuverability. The crawler performed well in simulant depths up to 3 inches. As depths increased to 4-6 inches, crawler operation became difficult. Adding more water to the simulant improved the crawler's mobility.

\section{Highbay Test}

The Highbay Test was conducted in 723-A. The test was a precursor to the TNX Full Tank Simulant Test. The objectives of the test were to:

- Develop coupling and de-coupling proficiency with the crawler and water monitor.

- Test the effectiveness of the remote hook in releasing and latching during the deployment of the crawler and water monitor.

- Determine the camera views needed to accomplish the coupling and de-coupling of the crawler and water monitor.

- Identify any cable management issues.

A riser mockup was fabricated and installed at a $42^{\prime}$ height in the Highbay facility. Multiple video cameras were strategically located to assist in the test. Testing personnel along with the crawler control and video monitoring equipment were staged on a level above the riser mockup. The remote hook was attached to the bridge crane. The crawler and water monitor were lowered through the riser and down onto the Highbay floor utilizing the video feed from the remote cameras placed at ground level.

The deployment process worked as planned. The crawler and water monitor were successfully passed through the riser. The crawler landed and unfolded as designed using its motorized tracks and attached springs. The remote hook disengaged easily from the crawler and the water monitor; the hook engaged easily as well when the crawler was retrieved. The crawler and water monitor were coupled and de-coupled remotely a number of times. The equipment was retrieved through the riser as well. It is important to note that the deployment process required multiple cameras to successfully align and couple the water monitor's adapter plate to the crawler's chassis.

\section{Full Tank Simulant Test}

The Full Tank Simulant Test was conducted at the TNX Full Tank Test Facility. The objective of this test was to determine how the crawler system performs in simulated tank conditions. There were a number of concerns involving the deployment of the crawler system. This test was performed to resolve the following issues:

- Determine the ability of the crawler and water monitor to be mated using a mobile crane.

- Determine the ability of the crawler and water monitor to be retrieved using a mobile crane.

- Determine crawler effectiveness in dragging cables and hoses in the tank.

- Determine the logistics of hose and cable management through the riser.

- Determine crawler effectiveness in negotiating obstacles and debris.

- Determine water monitor effectiveness in dislodging and moving the simulant tank sludge.

- Determine the stability of the crawler while spraying with the water monitor.

- Determine the most effective camera locations necessary to couple and de-couple the crawler and water monitor. 
Prior to the test, the tank was filled with water to a depth of approximately 8'. Roughly 200,000 pounds of dry kaolin were added to the tank using an EES designed nozzle. TNX operations personnel operated the Advanced Design Pump Mixer to blend the dry kaolin and water. The kaolin injection process required 2 days; the tank was subsequently allowed to settle for several days and then was drained. Unfortunately, the kaolin-based sludge simulant was extremely hydrated and the depth of the mixture varied from 5" to 12". It would have taken weeks for the sludge to thicken and decrease significantly in depth. The testing went forward despite the simulant depth and consistency problems.

Unforeseen testing difficulties with other tank closure equipment and subsequent scheduling problems caused the Full Tank Simulant Test to be conducted in 2 phases. The first phase of testing covered the first 5 of the aforementioned issues; the remaining issues were covered in the second phase. In both test phases, EES controlled and monitored the crawler and water monitor operation from an instrument shed located beside the full tank mockup.

The first phase of the test occurred in May 2000. As previously demonstrated in the Highbay test, multiple video cameras were needed to assist in the deployment, mating and operation of the crawler and water monitor. Therefore, 2 color video cameras with zoom, pan and tilt capabilities were installed in strategic tank locations, one on the side of the tank and one in the middle. The crane operator, with the assistance of a spotter, lowered the crawler and water monitor through the riser and onto the tank bottom. The spotter used video-display goggles that were integrated with the cameras. The cameras relayed in-tank video to the spotter who provided instructions to the crane operator. The spotter and crawler operator maintained radio contact and relied completely on the video feed to guide the entire coupling operation. Electricians located near the riser on the tank platform performed the cable management duties.

The crawler and associated cabling was lowered through the riser mockup, see Figures 8 and 9, and landed on the tank floor. It was driven back and forth beneath the riser to completely expand the frame, as shown in Figure 10. The water monitor, with its cable and hose attached, was then lowered through the riser mockup and into the tank, see Figures 11 and 12. The mating operation, illustrated in Figure 13, was performed a number of times and never took more than 25 minutes. Once coupled together, see Figure 14, the crawler and water monitor performed a number of tasks. The crawler was moved in a snake-like pattern across the tank floor, see Figure 15; the crawler traversed in a path that began at a spot below the mockup SE riser and ended at a location below the mockup NE riser. During testing, engineers verified that the crawler could maneuver with a water-laden hose, spray water while moving (see Figure 16), remotely adjust the spray pattern while spraying using the motorized nozzle, and crawl over obstacles such as banding straps.

The second phase of the testing was successfully completed in July 2000. A member of the Providence Group, a robotics subcontracting group associated with the Oak Ridge National Laboratory (ORNL), and several HLW personnel were present at this test. A tank heel was constructed in the mockup tank using kaolin clay and water, see Figure 17. For this test, one camera was repositioned at the riser opening while the other remained in the center of the tank. The crawler and water monitor were lowered through the riser and remotely coupled. The system was then lifted by crane into an area in the tank containing the tank heel. The crawler and spray system easily moved the simulant in the appropriate direction, see Figures $18-21$. Testing also showed that crawler stability was not affected when spraying at an angle or in close proximity to the tank wall, see Figures 22 and 23. Additional testing was performed after the test plan was completed. During this testing, the water monitor's pan motor failed. Subsequent investigation 
by MTS revealed that extensive corrosion had taken place in the pan motor housing. The complete investigation results can be found in the MTS document \#SRT-MTS-2000-40117, "Failure Analysis of Folded Tank Crawler Pan Motor (U)". New pan and tilt motors were purchased and installed.

The remote-controlled, motorized, 250 -gpm, spray nozzle generated far more water than the tank's pumps could remove in a timely manner. EES engineers replaced the 250 -gpm nozzle with the original 100-gpm, fixed spray pattern nozzle. The repaired water monitor and 100-gpm nozzle were tested with the assistance of the SRS Fire Department. As the water monitor was panned and tilted, the water pressure was varied between 60 and 100 psi. The water stream appeared more than adequate at these pressures.

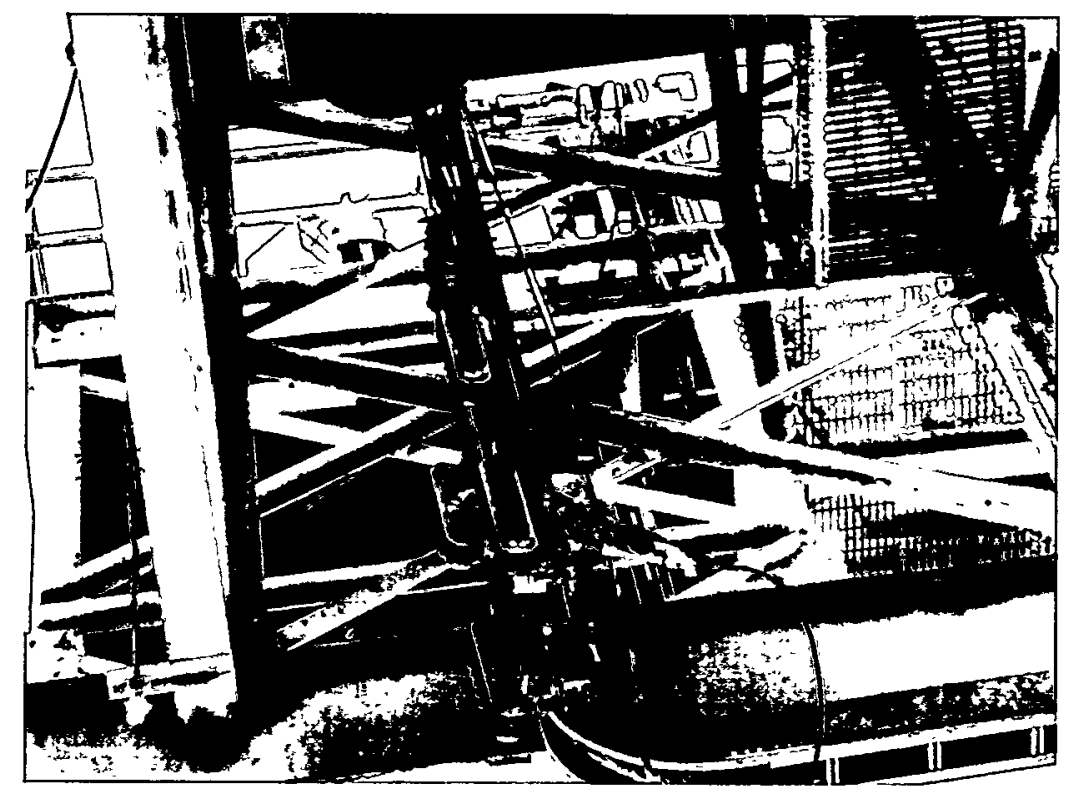

Figure 8. Crawler deployment through mockup riser 


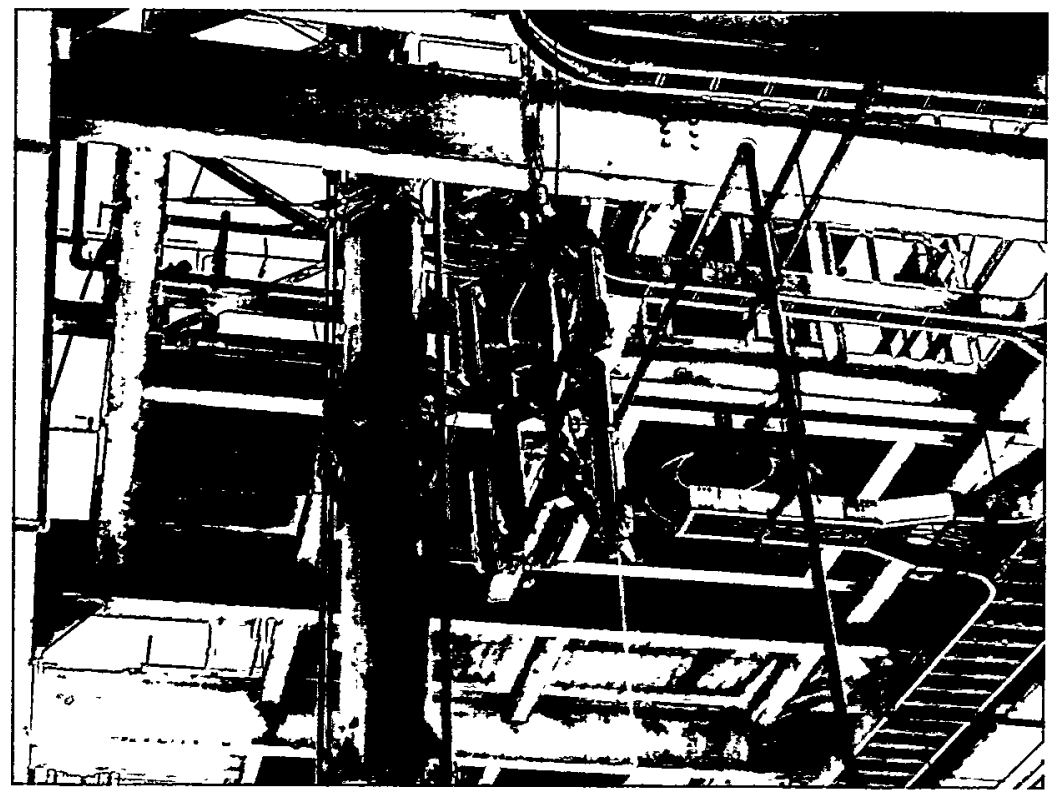

Figure 9. Crawler in folded position being lowered into mockup tank

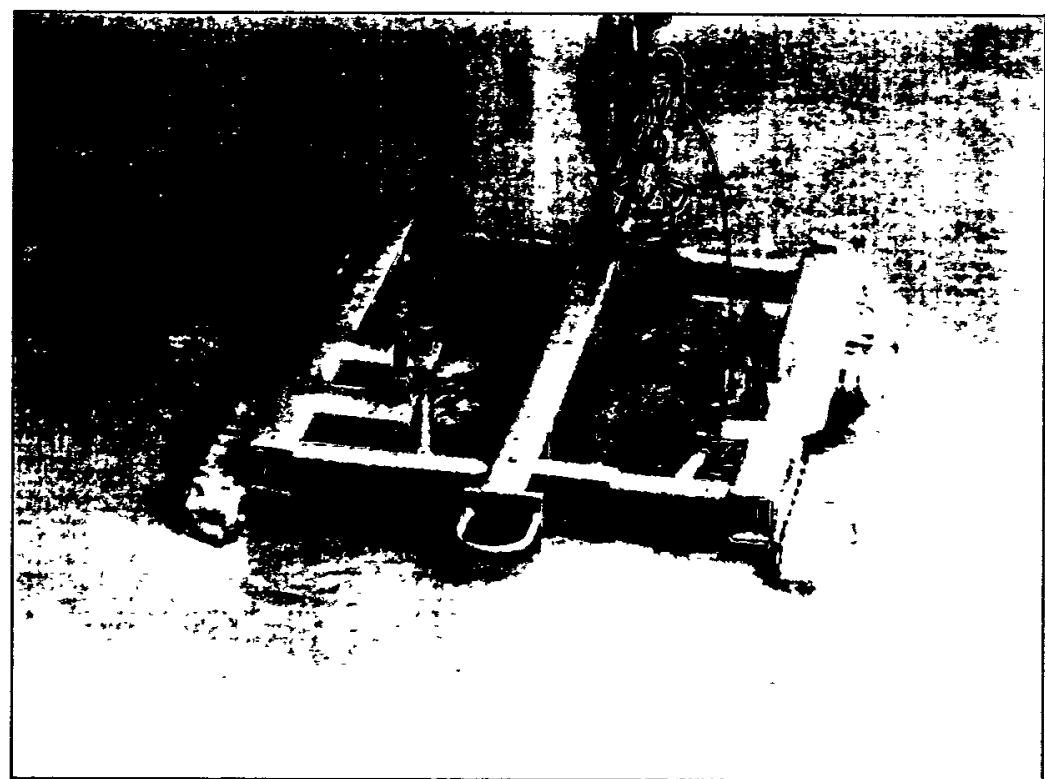

Figure 10. Crawler chassis expanded on mockup tank floor 


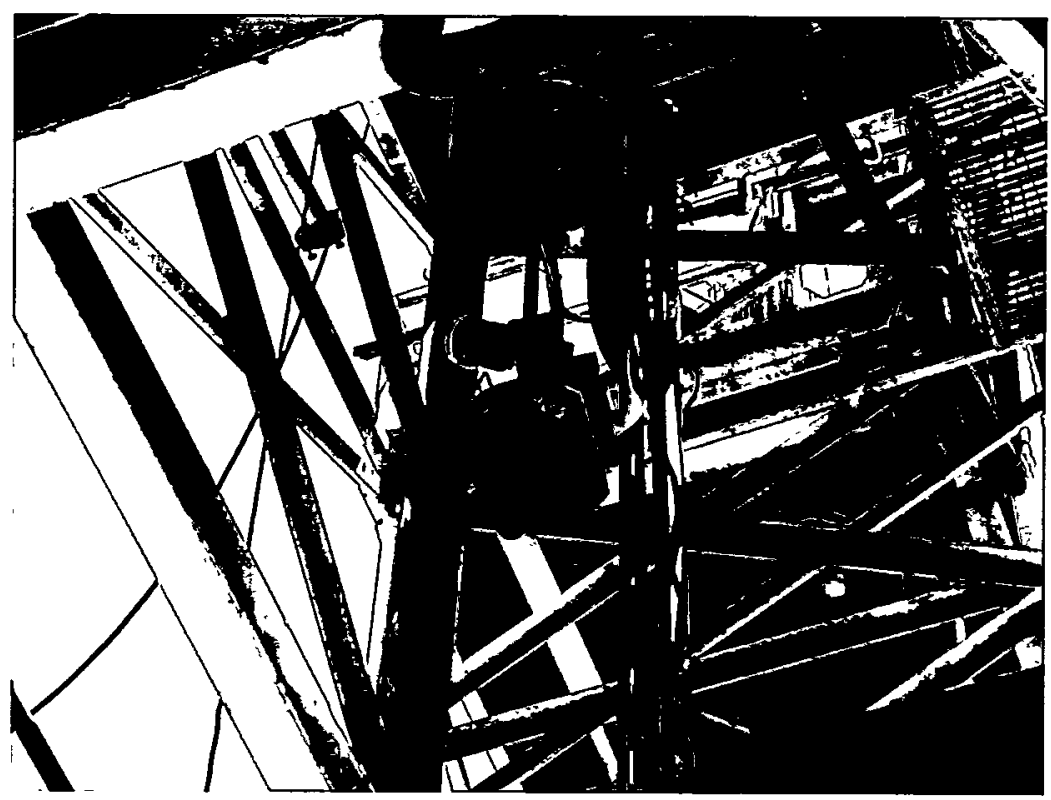

Figure 11. Water monitor/nozzle lowered through mockup riser

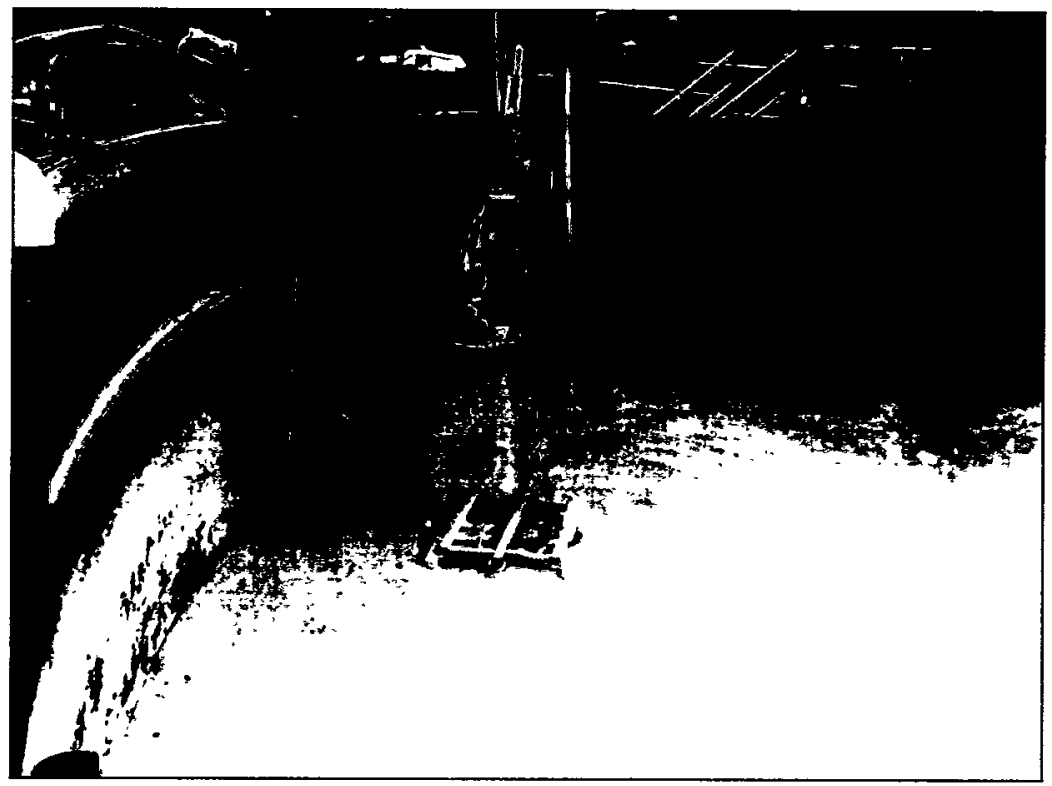

Figure 12. Water monitor/nozzle lowered into mockup tank 


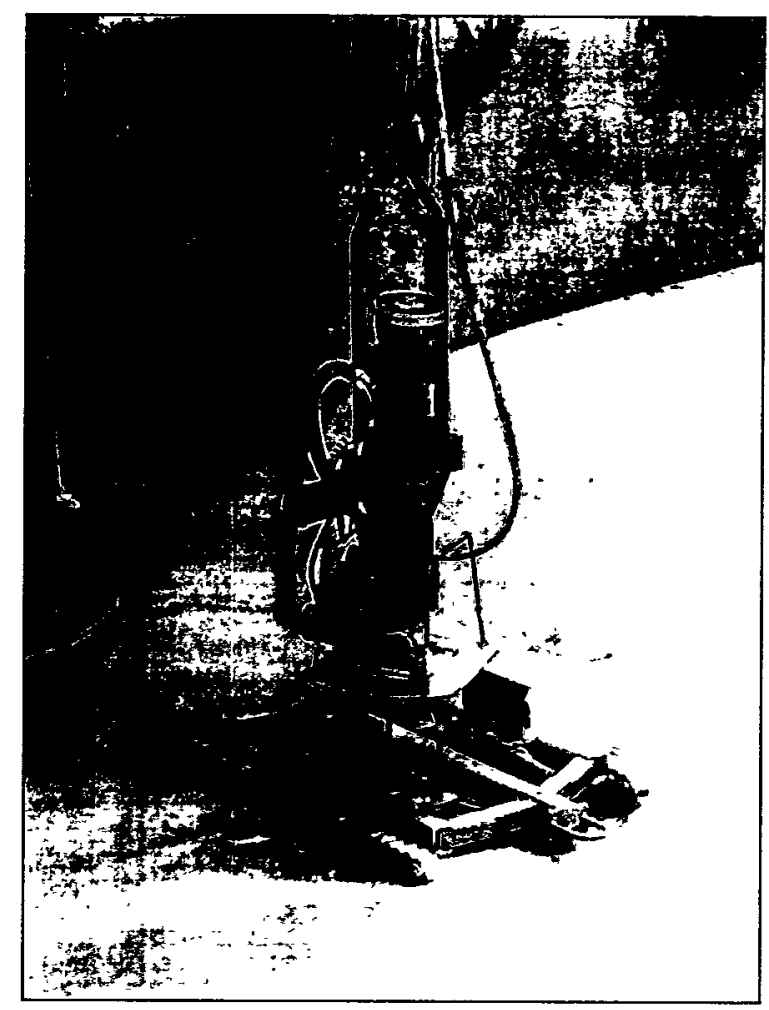

Figure 13. Water monitor/nozzle coupling operation with crawler chassis

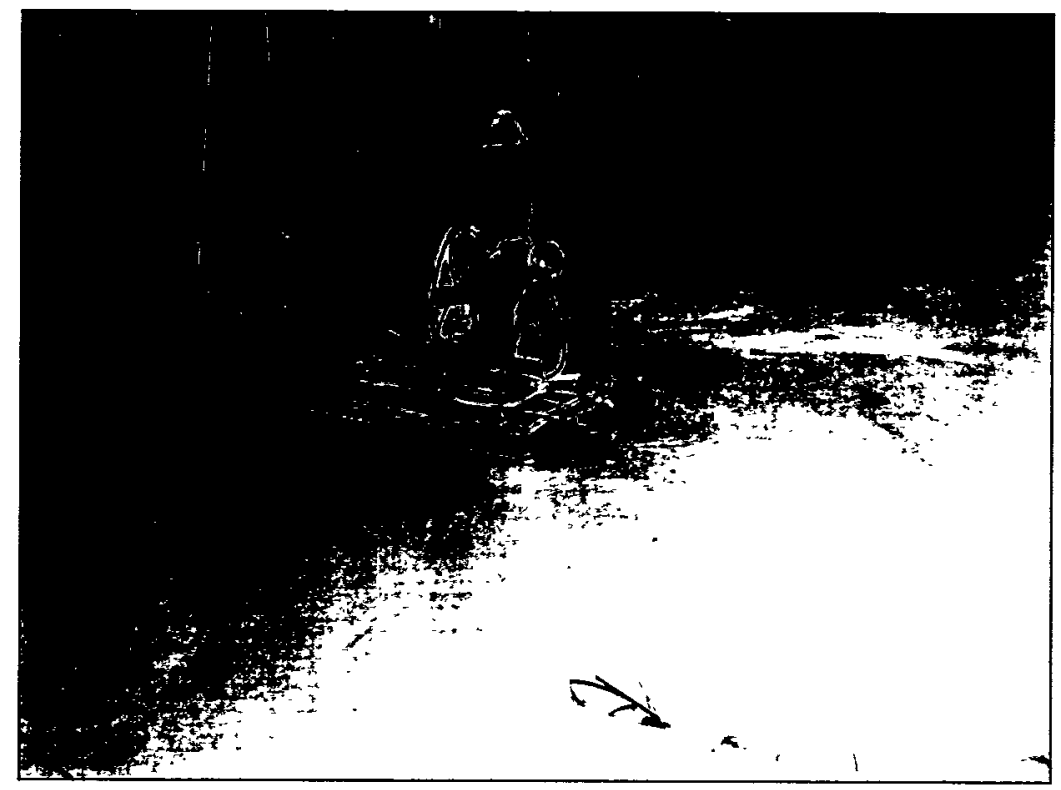

Figure 14. Crawler and water monitor ready for deployment in mockup tank 


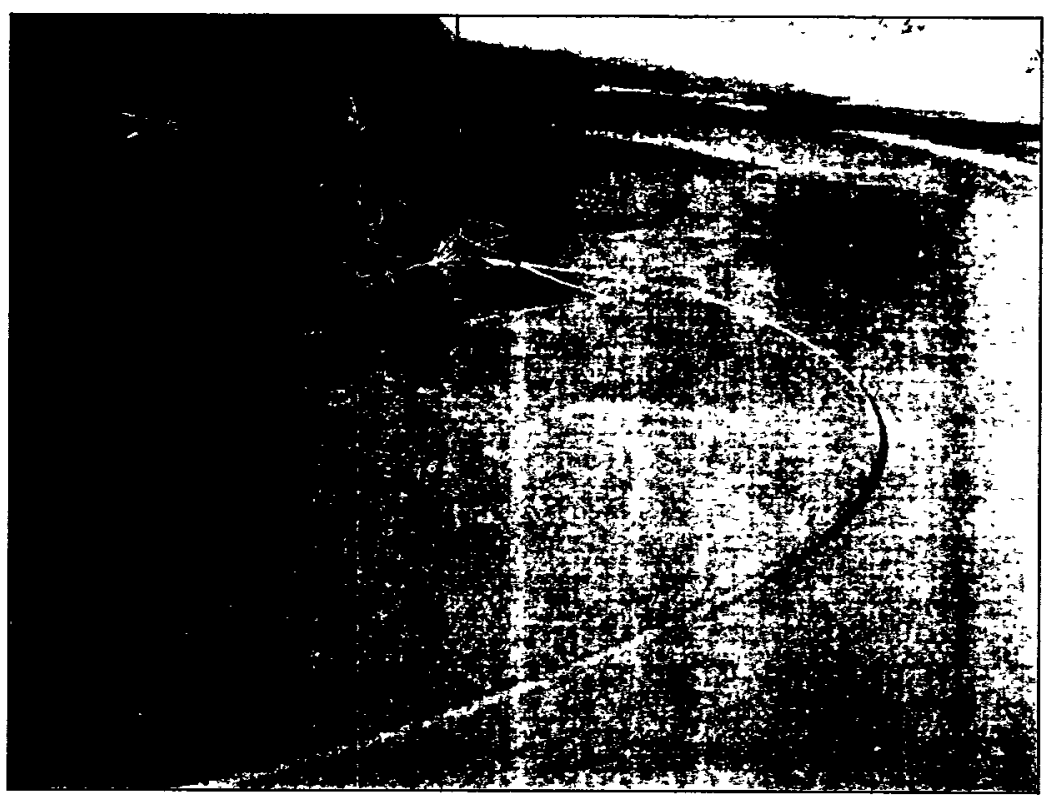

Figure 15. Crawler maneuvering and dragging water hose in mockup tank

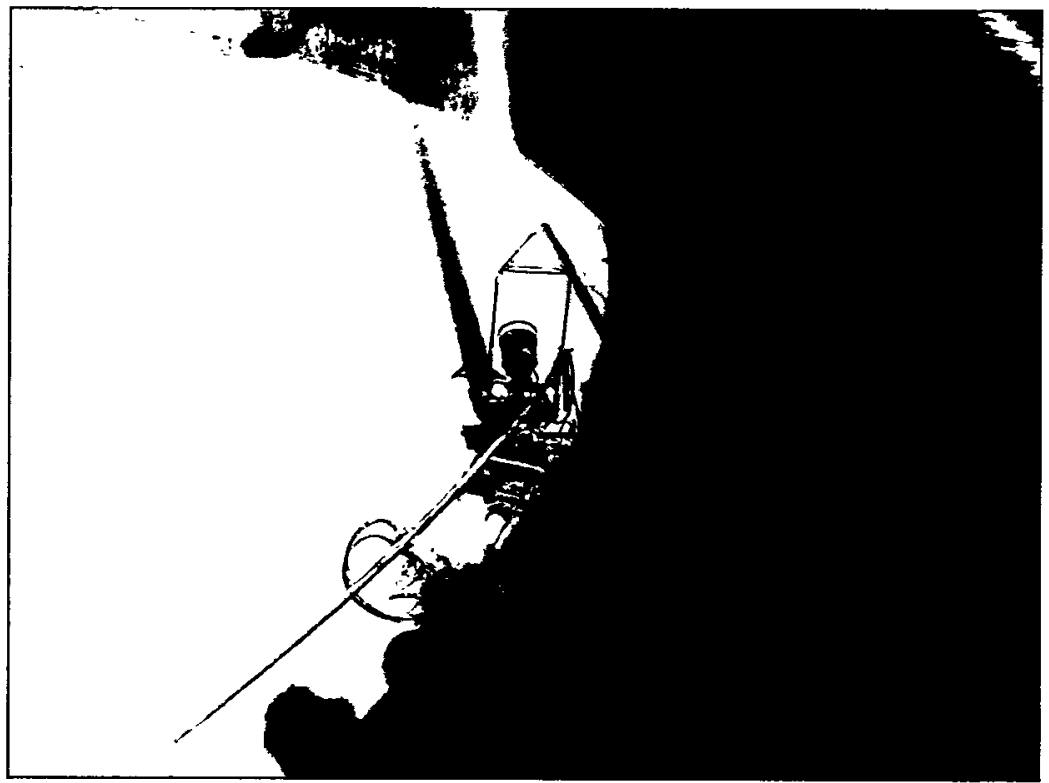

Figure 16. Crawler spraying while traversing mockup tank 


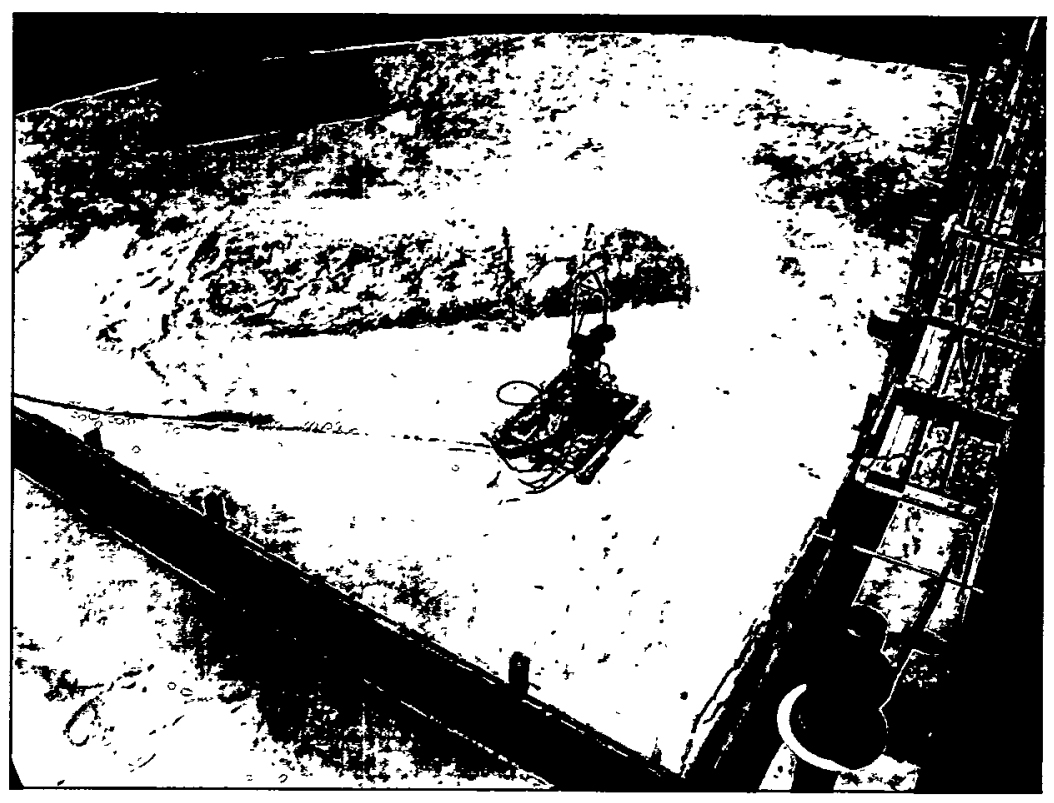

Figure 17. Tank heel and crawler ready for material removal tasks

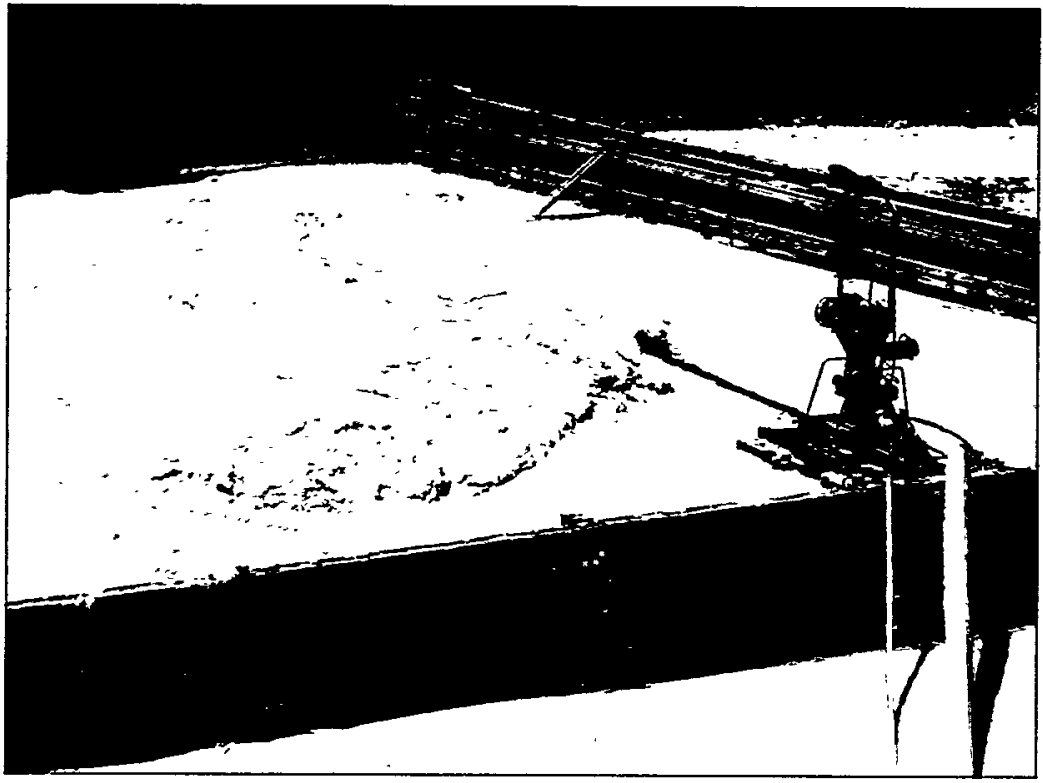

Figure 18. Nozzle blasting heel material 


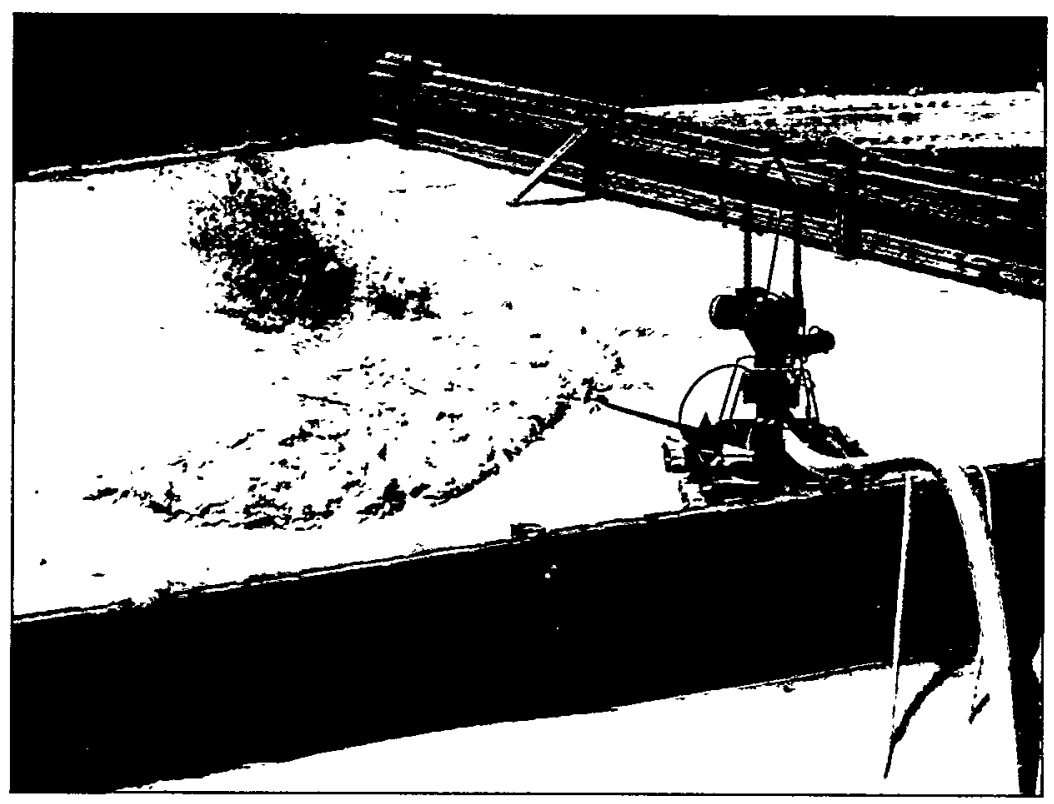

Figure 19. Nozzle blasting heel material

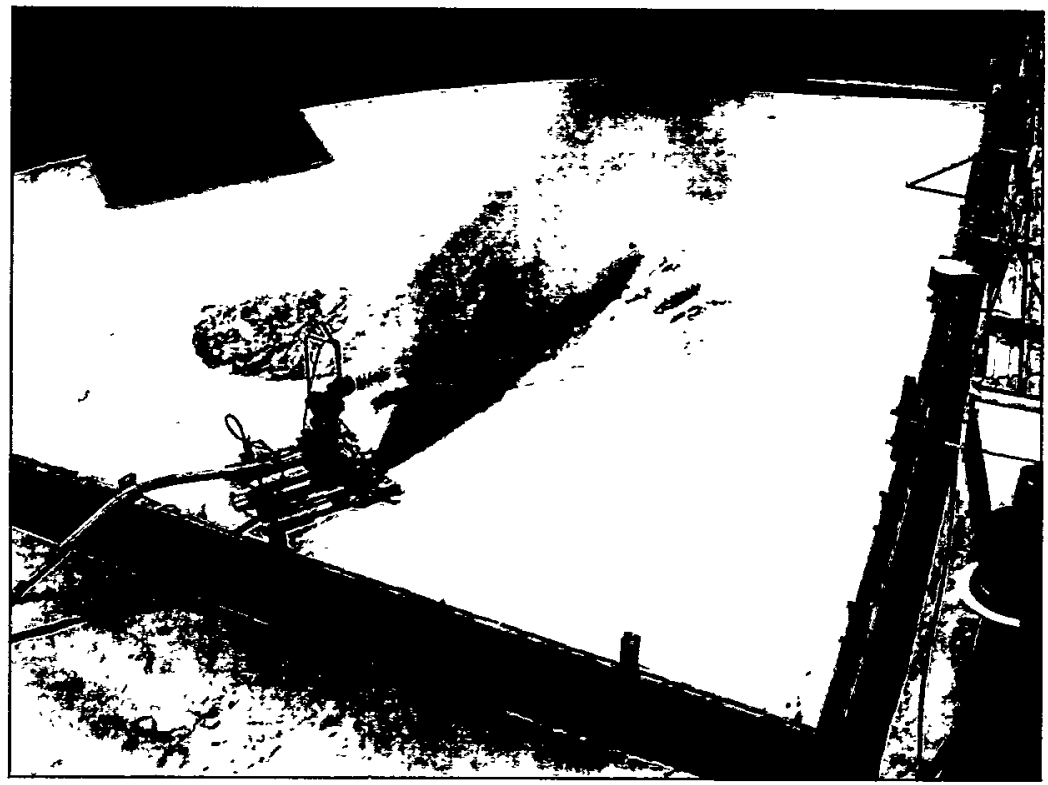

Figure 20. Nozzle blasting heel material 


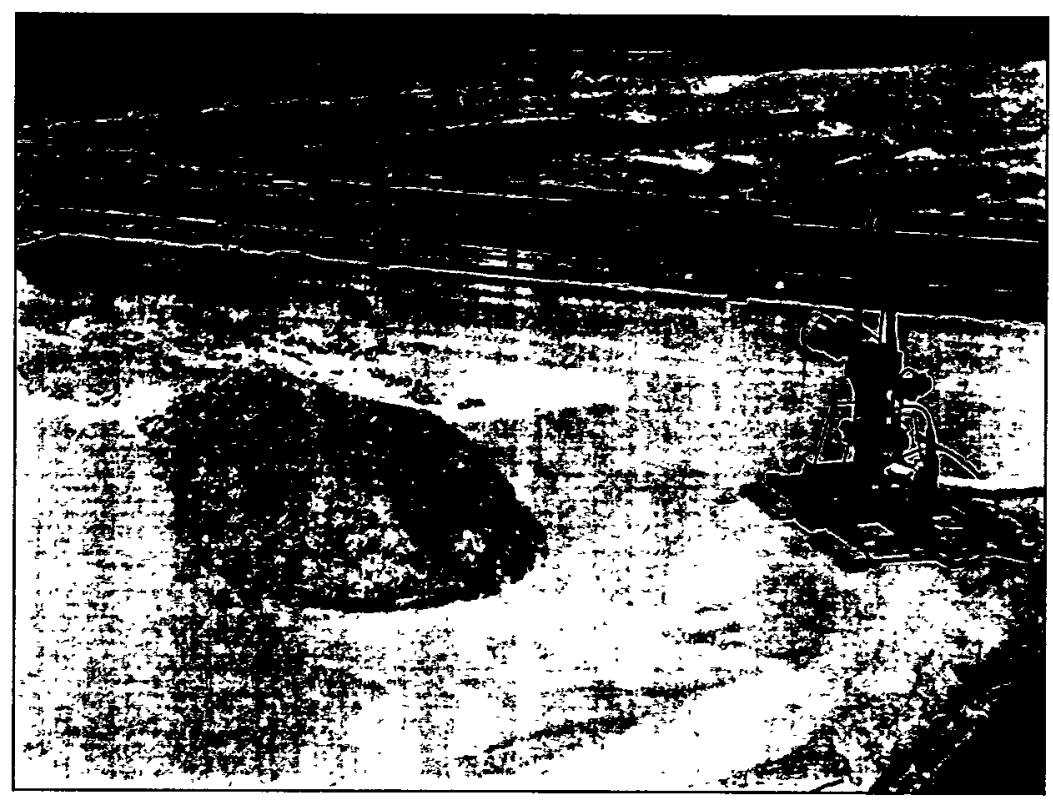

Figure 21. Heel after material has been displaced by nozzle

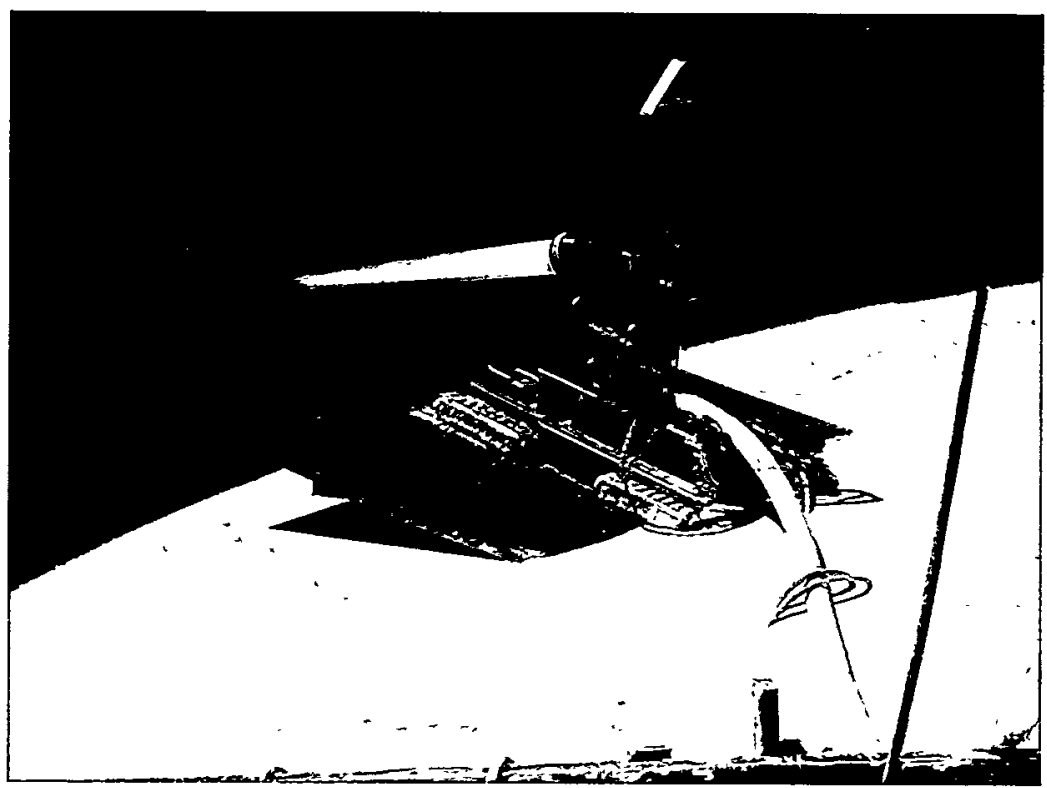

Figure 22. Crawler stability tested while spraying on an inclined surface 


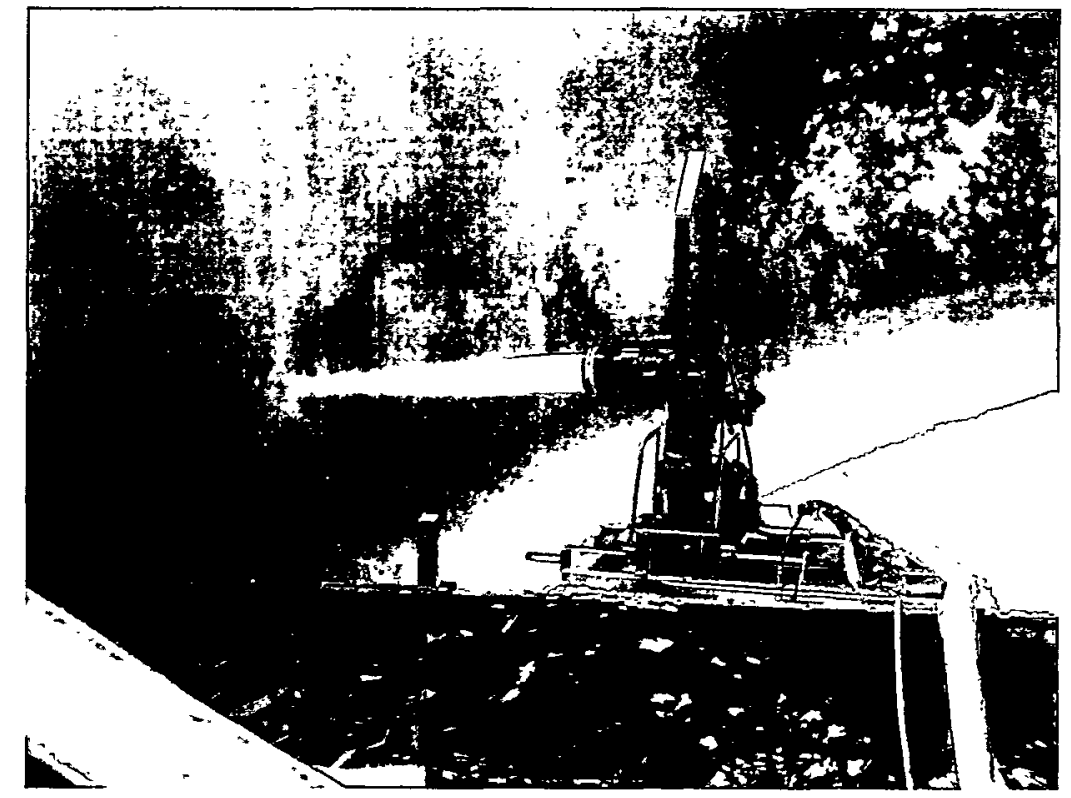

Figure 23. Crawler stability tested while spraying in close proximity to wall

\section{PERFORMANCE TEST SUMMARY}

A series of 4 tests in addition to the "parking lot test" were held to demonstrate various aspects of crawler and water monitor deployment and tank cleaning techniques. There were a number of concerns about the crawler design and the deployment approach. These concerns are summarized below for each test.

\section{Parking Lot Test}

- Stability of crawler system while spraying.

- Capability of the fixed nozzle to move solid material.

- Ability of the crawler to pull cables and a water-laden hose.

- Ability of the crawler to turn in place or "Skid Steer".

- Ability of the crawler to climb over a simulated tank heel.

\section{Riser Fit Test}

- Crawler clearance through a riser.

- Water monitor clearance through a riser.

\section{Traction Test}

- Tread problems caused by sludge.

- Effectiveness of crawler in sludge simulant.

- Mobility limitations imposed by sludge simulant depth. 


\section{Highbay Test}

- Deployment of the crawler through a riser.

- Landing of the crawler.

- Remote expansion of the crawler.

- Remote disengagement of the crawler from the remote hook.

- Deployment of the water monitor through a riser.

- Coupling the water monitor to the crawler.

- Remote disengagement of the water monitor from the remote hook.

- Remote engagement of the water monitor with the remote hook.

- Disengagement of the water monitor from the crawler.

- Retrieval of the water monitor through the riser.

- Remote engagement of the crawler with the remote hook.

- Remote folding of the crawler.

- Retrieval of the crawler through the riser.

\section{TNX Full Tank Test}

- Retrieval of the crawler and water monitor.

- Movement of a simulated sludge heel by the water monitor.

- Impact testing.

- Crawler stability with spray reaction force

- Crawler on flat surface

- Crawler on 10-15 degree incline

- Motorized nozzle range.

- Ability of the crawler to drag the hose and control cables.

- Camera locations to support deployment of the crawler and water monitor.

\section{CRAWLER SYSTEM IMPROVEMENTS}

Based on the FY00 performance tests, the following improvements were made and tasks performed on the system:

\section{Water Monitor}

1. Replaced the high flow, remotely adjustable nozzle with a low flow, manually adjustable nozzle.

2. Tested the manual nozzle under load.

3. Replaced the existing pan and tilt motors due to corrosion problems.

4. Attached a strain relief for the control cable.

5. Fabricated a spare adapter plate.

6. Purchased a spare water monitor.

7. Purchased a motorized, remote-controlled cable reel.

\section{Crawler Chassis}

1. Attached a strain relief for the control cable.

2. Replaced the expansion springs.

3. Purchased a motorized, remote-controlled cable reel. 


\section{CRITICAL ISSUES}

The performance tests provided valuable information. After a thorough evaluation of the test results, the EES design team agrees successful deployment of this crawler system depends on 4 critical issues:

1. Adequate in-tank camera support.

2. Proper cable management.

3. Depth and consistency of the tank sludge.

4. Condition of the landing zone beneath the riser.

In the Full Tank Simulant Test, 2 cameras were used to help mate the crawler and water monitor. The cameras were placed in locations similar to positions that will be available on Tank 19F. Our collective experience in remote-operations shows that the crawler system cannot be deployed without adequate lighting or proper positioning of the cameras. There are two guide pins on the crawler platform and one small wedge plate on the water monitor plate that the operator and spotter must see in order to couple the crawler and water monitor together.

Cable management is also a challenge that must be dealt with carefully. This issue is of special concern in a radioactive environment where personnel contamination must be avoided. Any equipment and associated cabling inserted into the tank will get contaminated. Personnel may have to retrieve the crawler control cable during operation to prevent the crawler from running over it as well as having to make a repair to the crawler. EES engineers believe that motorized cable reels will help prevent unnecessary radiation exposure to workers and reduce contamination incidents. EES engineers ordered motorized reels for cable management. However, these reels must be integrated into the system and tested prior to use.

Another important issue is the depth of the supernate and sludge. The depth of these tank constituents affects the water monitor's operation as well as crawler and water monitor coupling. The water monitor's pan motor failure was due to water infiltration. The pan motor should be kept above the supernate. Also, coupling will be difficult if the depth of the supernate is more than 6" (the latching slot for the crawler and water monitor will not be visible) and impossible if the supernate is more than 10" deep (the guide pins will not be visible). As observed in the Traction Test, the crawler has difficulty moving if the sludge is more than 3" deep due to frame interference. The crawler needs to be able to move beneath the riser to fully expand and accept the water monitor. Consistency of the sludge is another factor. During the Traction Test, adding water to simulant sludge greater than 3" deep actually increased the crawler's mobility. So the crawler can navigate in sludge greater than 3" deep if it is soupy as demonstrated in the TNX Full Tank Test.

Finally, the landing zone beneath the riser must be free of obstructions. Also, the tank floor under the deployment riser must be level within 5 degrees of horizontal to successfully couple the crawler and the water monitor. 


\section{RECOMMENDATIONS}

The crawler and water monitor system met or exceeded expectations in the performance tests. EES makes the following recommendations based on lessons learned from the tests.

\section{Cameras and Lighting}

1. Contact the organization responsible for in-tank video surveillance and develop a plan for strategic camera placement and appropriate lighting levels.

\section{General}

1. Develop a cable and hose management system using remote-controlled reels.

2. Purchase a spare crawler.

3. Purchase a spare water monitor.

4. Test the crawler and water monitor together with the tank pump system.

\section{Deployment and Operating Guidelines}

1. Use a riser sleeve with rollers to eliminate friction on the cables and hose.

2. Maintain tension on the control cables.

3. Avoid tank obstacles if possible.

4. Wash the cables, hose, crawler and water monitor prior to retrieval back through the riser.

\section{REQUIREMENTS FOR FIELD DEPLOYMENT AND OPERATION}

\section{Facility and Services}

1. Store the system's control cabinet in an air-conditioned building.

2. Protect the crawler and water monitor from rain and direct sun.

3. Provide 110-120 VAC @ 20 amps for crawler and water monitor controls.

4. Provide clean water at a maximum pressure of $100 \mathrm{psi}$.

5. Install a pressure gauge in the water supply line to ensure that pressure is not exceeded.

6. Provide a ground fault circuit interrupter (GFCD).

\section{Tank Top}

1. 23" diameter riser.

2. Dedicated riser for crawler system deployment.

\section{Tank Bottom}

1. Unobstructed floor under the access riser.

2. Supernate level - 6" depth or less.

3. Sludge, salt, or other solids level -3 " depth or less.

\section{Pre-deployment Functions}

1. Operate pan \& tilt motors on the water monitor.

2. Operate the tracks forward and backward.

3. Test the camera functions.

4. Test the video recording system.

5. Test and confirm the following connections
a. Control cable connection to crawler
b. Hose connection to water monitor
c. Strain relief connection on water monitor
d. Strain relief connection on crawler 


\section{Deployment and Operating Guidelines}

1. Use multiple cameras at different angles to assist with system coupling and navigation.

2. Do not drive the crawler over the hose or control cables.

3. Do not drag the crawler hose and cables under the mixers.

\section{CONCLUSIONS}

In accordance with Technical Assistance Request \#HLE-TTR-1998-031, Rev. 1, and WAD \# WT109052, EES procured components and provided design engineering support to fabricate, assemble, test, and demonstrate a remote-controlled crawler system to transport a water monitor within a waste tank.

The primary design considerations included the following:

- Carry a payload of 100 pounds.

- Be compatible with tank chemistry and radiation levels.

- Fit through an existing 23" diameter riser.

- Maintain sufficient traction in sludge and maneuverability around obstacles.

- Estimated 3-month life (one-time use in a waste tank).

- Minimal equipment costs.

An inexpensive, off-the-shelf, remotely controlled, drive train was identified as a suitable candidate for the crawler platform. A material analysis of the drive train was performed with regard to tank chemistry and radiation levels. Material substitutions were made. A set of 4 stainless steel drive trains was purchased along with a controller. A folding chassis incorporating the drive trains was designed to insert through a tank riser. The water monitor payload was too large to permanently attach to the chassis and deploy together through the riser access. An adapter plate was fabricated for independent deployment of the water monitor. The adapter plate allowed the water monitor to be remotely coupled with the crawler from within the tank. The process for deploying the system was successful. Tests and demonstrations were conducted that highlighted the ability of the crawler and water monitor system to successfully maneuver in the tank and move simulant sludge where directed. Some improvements were made to the system as a result of the testing. EES engineers found that strategic camera placement, appropriate in-tank lighting, condition of the landing zone and tank floor, depth and characteristics of the tank waste, and cable and hose management are critical factors to the success of the Tank 19F Folding Crawler system.

The crawler system is comprised of reusable and one-time use components. The reusable components include the crawler's controller and the water monitor's controller. The cost of this equipment is approximately $\$ 20 \mathrm{~K}$. The one-time use or in-tank components include the crawler's tracks, wiring harness, tether, folding frame, the water monitor, nozzle, cable and hose. The cost of this equipment is approximately $\$ 80 \mathrm{~K}$. The bare cost of producing another crawler system is approximately $\$ 100 \mathrm{~K}$. 
APPENDIX A - AKRON BRASS WATER MONITOR AND NOZZLE 
A complete line of compact, low profile monitors available in lightweight Pyrolite ${ }^{\otimes}$ and rugged brass designed to meet today's fire fighting needs. These split waterway deck pipe monitors are avallable for manual, hydraulic, or electric operation. All Gemini Monitors are designed for maximum efficiency.

- Low friction loss - no more than 10 psi loss at 1000 gpm.

- $3^{\prime \prime}$ or 4 " NPT female or flange inlet

- Outlet thread : $2^{1 / 2}$ " on $3470-78$

$$
31 / 2^{\prime \prime} \text { on } 3370-78
$$

- Vertical travel of $45^{\circ}$ below to $90^{\circ}$ above horizontal (Pyrolite models have a removable stop at $45^{\circ}$ above horizontal to meet NFPA - 1901)

\section{- High volume -3470-78 - flows up to $1000 \mathrm{gpm}$ at 100 psi} 3370-78 - flows up to $1500 \mathrm{gpm}$ at $85 \mathrm{psi}$

\section{Gemini Electric Monitors}

Exclusive Automatic Override feature allows both control boxes to be operational at the same time. If both are simultaneously activated only the lower (remote) control will operate the unit. Also, a built-in diode helps prevent accidental battery discharge.

- All electric with built-in clutches

- Flexible - Two control boxes plus optional tether and third control box

- Remote control of horizontal, vertical and pattern movement

- 12 volt $D C$ electric operation 24 volt optional

- Optional battery pack reduces wire size requirements and alds in emergency operation

- Easy installation

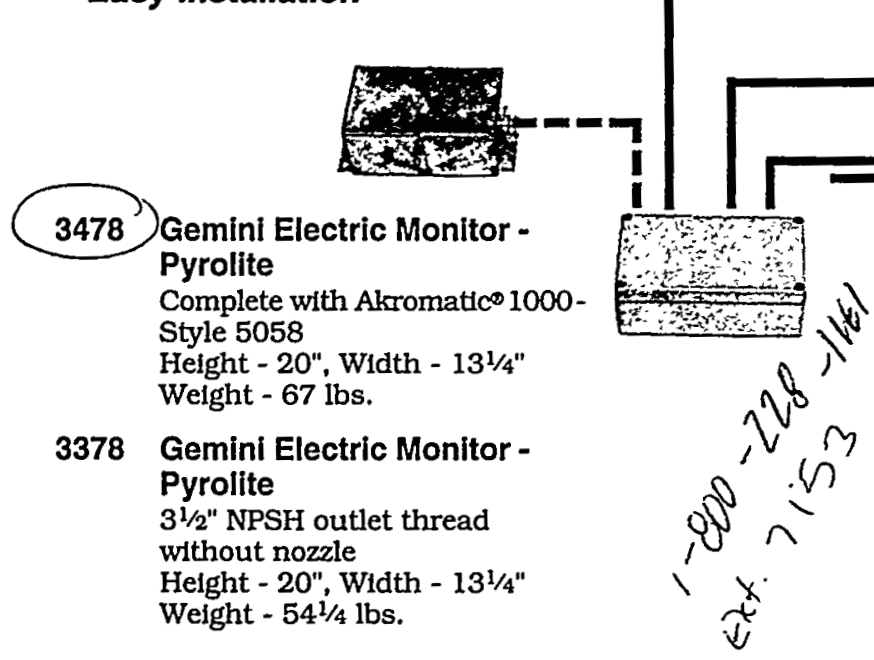

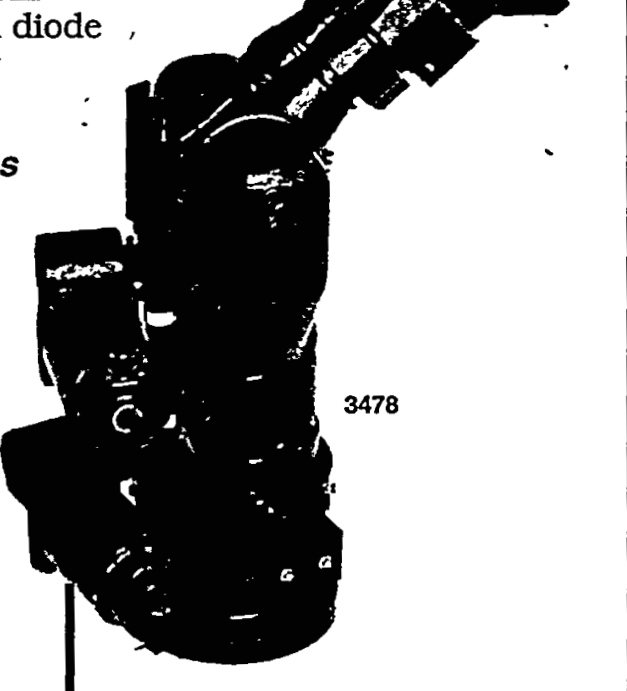
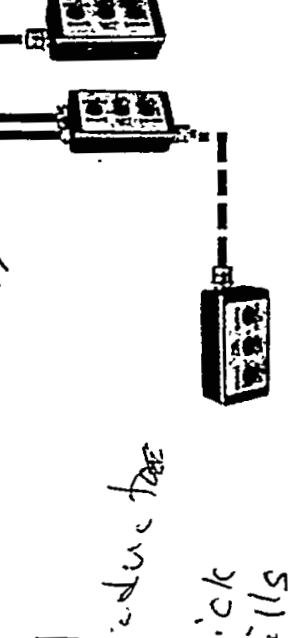

How to Specifinto (i: Style 3478

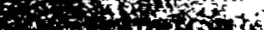
The monitor is to $\mathrm{be}$ an all $\mathrm{x}$, Pelectricaliy controlied split

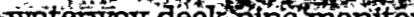

$x$ ateray deckiplpenonitor

constructed oflightweight

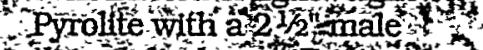

thread discharge mFriction loss

not to exceed 10 psinteo 00

gpn ine mon tor hould

7 include ${ }^{2}$ antomatic 350 to

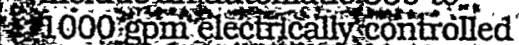

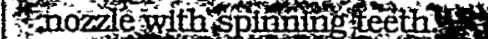

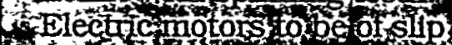

Sulutch design to prevent

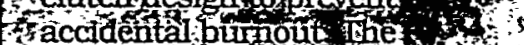

omonitor is hot to exced 20 "

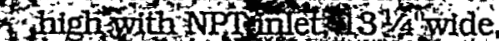

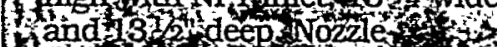

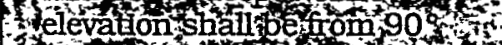

3 aboretorizontal o 55 bu

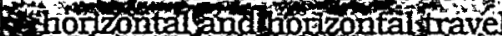

* shail be up to 335 . Whe

monfitor shall include contul

boxestandifelay box

Notes or stie 3378 changero . 3 a nale discharge wotho

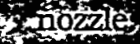

$x$.

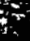

r.t.
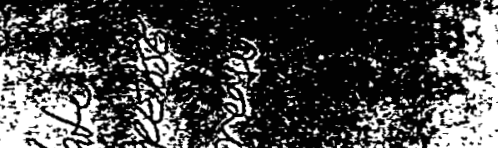

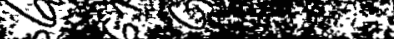

to

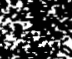

sis

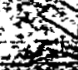

tit?
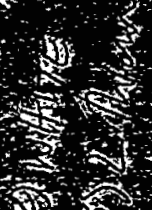

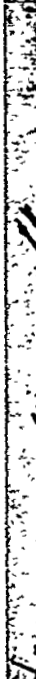

ix.

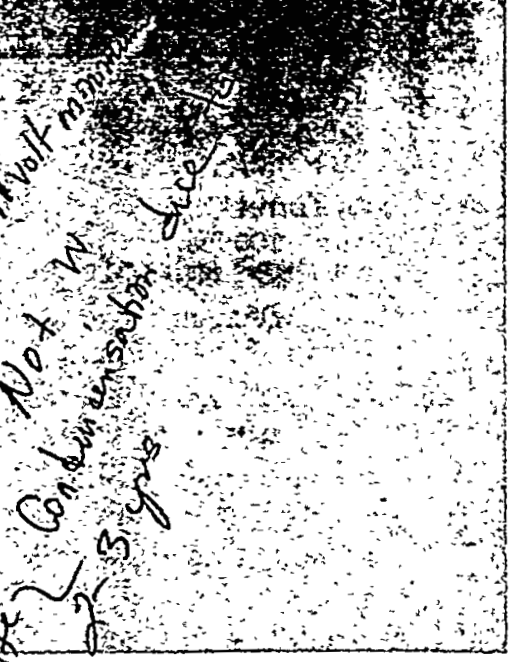

2)

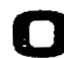


An automatic nozzle is designed to maintain a consistent operating pressure over a wide range of flows.

Akron's Mid-Range Akromatic ${ }^{\circledR}$ automatic nozzle offers excellent flow patterns, flow control, and consistent nozzle pressure, all in one package. Choose between the excellent fog pattern of spinning teeth and the durability of the patented double row of molded teeth.This $60-200 \mathrm{gpm}(230-750 \mathrm{lpm})$ nozzle is designed for $1 \frac{1 / 2 "}{}$, $1^{3 / 4}$ " and 2 "lines.

The Akromatic is the only automatic nozzle available with a Volume Control Ring (VCR) designed to provide the operator with positive flow control (see facing page for details).

- Constant gallonage combination fog/straight stream

- Pyrolite ${ }^{\oplus}$ construction for durability and lightweight operation

- Hydraulically balanced piston for more consistent nozzle pressure

- Available with Volume Control Ring limits 100,150 , and $200 \mathrm{gpm}$

- Pattern Detents for positive pattern positioning

- Specially contoured Pistol Grip for maximum comfort

- Flush without shutting down

- Compatible with standard AFFF and Class A foams

- Ideal for use with Eductors and Quick-Attack ${ }^{\text {nu }}$ Foam Tubes

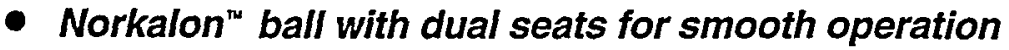

- Heavy-duty Handle with Dual Handle Stops

- Storz and British Instantaneous connections available

Mid-Range Akromatic with

Double Row Molded Teeth

5014 Tip

$1^{1 / 2 "}$ Rigid Base

Length $-7^{3 / 4^{11}}$, Weight $-4^{3 / 8} \mathrm{lbs}$.

5015 Nozzle

$1^{1 / 2 "}$ Swivel

Length - $10^{1 / 21}$

Weight - $5^{3 / 4} \mathrm{lbs}$.

5016 Nozzle with Pistol Grip 11/2" Swivel

Length $-10^{1 / 2 n}$, Weight $-6^{1 / 8} \mathrm{lbs}$.

5017 Breakapart Nozzle

$1 \frac{1}{2}$ " Swivel

5014 Tp +2129 Shutoff

Length $-11^{5 / 8^{\prime \prime}}$, Weight $-6^{1 / 8} \mathrm{lbs}$.
5018 Breakapart Nozzle with Pistol Grip

$1 \frac{1}{2}$ " Swivel

5014 Tip +2127 Shutoff

Length - $11^{5 / 8}$, Welght - $61 / 2 \mathrm{lbs}$.

Mid-Range Akromatic with

Double Row Molded Teeth and

Volume Control Ring (VCR)

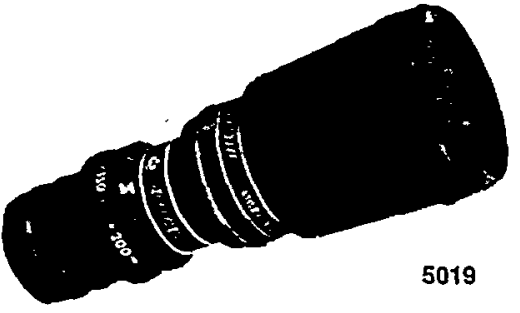

5019 Tip

$I^{1 / 2 " \text { Swivel }}$

Length $-9^{3 / 4} 4^{\prime}$, Weight $-5^{1 / 3}$ lbs

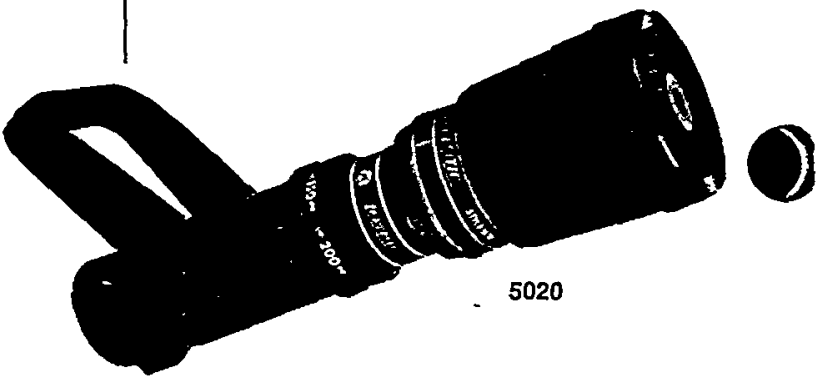

5020 Nozzle

$1^{1 / 2 " \text { Swivel }}$

Length $-12^{1 / 2} 2^{\prime}$, Weight $-6^{1 / 2}$ lbs.

5021 Nozzle with Pistol Grip $1^{1 / 2}$ " Swivel

Length $-12^{1 / 2} 2^{\prime}$. Weight $-6^{7 / 8} \mathrm{lbs}$.

5022 Breakapart Nozzle

$1^{1 / 2}$ " Swivel

5019 Tip +2129 Shutoff

Length - $14^{1 / 8 "}$, Weight $-6^{7 / 8} \mathrm{lbs}$.

5023 Breakapart Nozzle with Pistol Grip

$11 / 2$ " Swivel

5019 Tip +2127 Shutoff $\cdot$

Length - $14^{1 / 8 "}$, Weight $-7^{1 / 4}$ lbs. 
AKROMATIC

\begin{tabular}{|c|c|c|c|c|c|c|c|c|}
\hline \multirow{3}{*}{ Style } & \multirow{2}{*}{\multicolumn{2}{|c|}{$\begin{array}{c}\text { Nozzle } \\
\text { Pressure }\end{array}$}} & \multirow{2}{*}{\multicolumn{2}{|c|}{ Actual Flow }} & \multicolumn{4}{|c|}{ Straight Stream Reach } \\
\hline & & & & & \multicolumn{2}{|c|}{ Effective } & \multicolumn{2}{|c|}{ Overall } \\
\hline & psi & bar & gpm & Ipm & Feet & Meters & Feet & Meters \\
\hline $\begin{array}{c}\text { MID } \\
\text { RANGE } \\
\text { AKROMATIC }\end{array}$ & 100 & 6.89 & $\begin{array}{r}60 \\
100 \\
125 \\
150 \\
175 \\
200\end{array}$ & $\begin{array}{l}230 \\
380 \\
475 \\
550 \\
660 \\
750\end{array}$ & $\begin{array}{r}80 \\
108 \\
110 \\
115 \\
127 \\
127\end{array}$ & $\begin{array}{l}24 \\
33 \\
34 \\
35 \\
39 \\
39\end{array}$ & $\begin{array}{l}100 \\
123 \\
126 \\
137 \\
150 \\
150\end{array}$ & $\begin{array}{l}30 \\
37 \\
38 \\
42 \\
46 \\
46\end{array}$ \\
\hline$\underset{I I}{\text { AKROMATIC }}$ & 100 & 6.89 & $\begin{array}{l}100 \\
125 \\
150 \\
200 \\
250 \\
300 \\
350 \\
375\end{array}$ & $\begin{array}{r}380 \\
475 \\
550 \\
750 \\
950 \\
1140 \\
1325 \\
1420\end{array}$ & $\begin{array}{l}105 \\
115 \\
122 \\
142 \\
145 \\
147 \\
148 \\
150\end{array}$ & $\begin{array}{l}32 \\
35 \\
37 \\
43 \\
44 \\
45 \\
45 \\
46\end{array}$ & $\begin{array}{l}126 \\
130 \\
143 \\
160 \\
161 \\
165 \\
169 \\
170\end{array}$ & $\begin{array}{l}38 \\
40 \\
44 \\
49 \\
49 \\
50 \\
52 \\
52\end{array}$ \\
\hline
\end{tabular}

SOLID BORE TIPS

\begin{tabular}{|c|c|c|c|c|c|c|c|c|c|}
\hline \multirow{3}{*}{ Style } & \multirow{3}{*}{ Size } & \multirow{2}{*}{\multicolumn{2}{|c|}{$\begin{array}{c}\text { Nozzle } \\
\text { Pressure }\end{array}$}} & \multirow{2}{*}{\multicolumn{2}{|c|}{ Actual Flow }} & \multicolumn{4}{|c|}{ Straight Stream Reach } \\
\hline & & & & & & \multicolumn{2}{|c|}{ Effective } & \multicolumn{2}{|c|}{ Overall } \\
\hline & & psi & bar & gpm & Ipm & Feet & Meters & Feet & Meters \\
\hline \multirow[t]{2}{*}{1430} & $1 / 2 "$ & $\begin{array}{l}50 \\
80\end{array}$ & $\begin{array}{l}3.5 \\
5.5\end{array}$ & $\begin{array}{l}53 \\
66\end{array}$ & $\begin{array}{l}201 \\
250\end{array}$ & $\begin{array}{r}97 \\
121\end{array}$ & $\begin{array}{l}30 \\
37\end{array}$ & $\begin{array}{l}110 \\
140\end{array}$ & $\begin{array}{l}34 \\
43\end{array}$ \\
\hline & $7 / 8 "$ & $\begin{array}{l}50 \\
80\end{array}$ & $\begin{array}{l}3.5 \\
5.5\end{array}$ & $\begin{array}{l}159 \\
201\end{array}$ & $\begin{array}{l}602 \\
761\end{array}$ & $\begin{array}{l}130 \\
156\end{array}$ & $\begin{array}{l}40 \\
48\end{array}$ & $\begin{array}{l}150 \\
175\end{array}$ & $\begin{array}{l}46 \\
53\end{array}$ \\
\hline \multirow[t]{2}{*}{439} & $1 / 2^{\prime \prime}$ & $\begin{array}{l}50 \\
80\end{array}$ & $\begin{array}{l}3.5 \\
5.5\end{array}$ & $\begin{array}{l}53 \\
66\end{array}$ & $\begin{array}{l}201 \\
250\end{array}$ & $\begin{array}{r}94 \\
106\end{array}$ & $\begin{array}{l}29 \\
32\end{array}$ & $\begin{array}{l}102 \\
123\end{array}$ & $\begin{array}{l}31 \\
37\end{array}$ \\
\hline & $15 / 16^{\prime \prime}$ & $\begin{array}{l}50 \\
80\end{array}$ & $\begin{array}{l}3.5 \\
5.5\end{array}$ & $\begin{array}{l}182 \\
230\end{array}$ & $\begin{array}{l}689 \\
871\end{array}$ & $\begin{array}{l}142 \\
175\end{array}$ & $\begin{array}{l}43 \\
53\end{array}$ & $\begin{array}{l}162 \\
195\end{array}$ & $\begin{array}{l}49 \\
59\end{array}$ \\
\hline
\end{tabular}

AKROMATIC 1250

\begin{tabular}{|c|c|c|c|c|c|c|c|c|}
\hline \multirow{3}{*}{ Style } & \multirow{2}{*}{\multicolumn{2}{|c|}{$\begin{array}{c}\text { Nozzle } \\
\text { Pressure }\end{array}$}} & \multirow{2}{*}{\multicolumn{2}{|c|}{ Actual Flow }} & \multicolumn{4}{|c|}{ Straight Stream Reach } \\
\hline & & & & & \multicolumn{2}{|c|}{ Effective } & \multicolumn{2}{|c|}{ Overall } \\
\hline & psi & bar & gpm & Ipm & Feet & Meters & Feet & Meters \\
\hline 5060 & 100 & 6.89 & $\begin{array}{c}500 \\
750 \\
1000 \\
1250\end{array}$ & $\begin{array}{l}1900 \\
2900 \\
3800 \\
4800\end{array}$ & $\begin{array}{l}200 \\
220 \\
260 \\
290\end{array}$ & $\begin{array}{l}61 \\
67 \\
79 \\
88\end{array}$ & $\begin{array}{l}230 \\
250 \\
290 \\
320\end{array}$ & $\begin{array}{l}70 \\
76 \\
88 \\
97\end{array}$ \\
\hline
\end{tabular}

Reach figures are measured with nozzle at $32^{\circ}$ angle above horizontal. Overall reach is considered where farthest droplets of water fall, in still conditions. Effective reach is considered the farthest portion of the water droplet foot print where effective fire fighting can be accomplished, in still conditions. Data supplied from tests conducted under ideal conditions. Actual flow will vary depending on conditions. Nozzles are designed and rated at 100 psi. Higher or lower pressures will result in lower flows. 
APPENDIX B - INUKTUN CRAWLER 


\section{The MiniTracs Transport System}

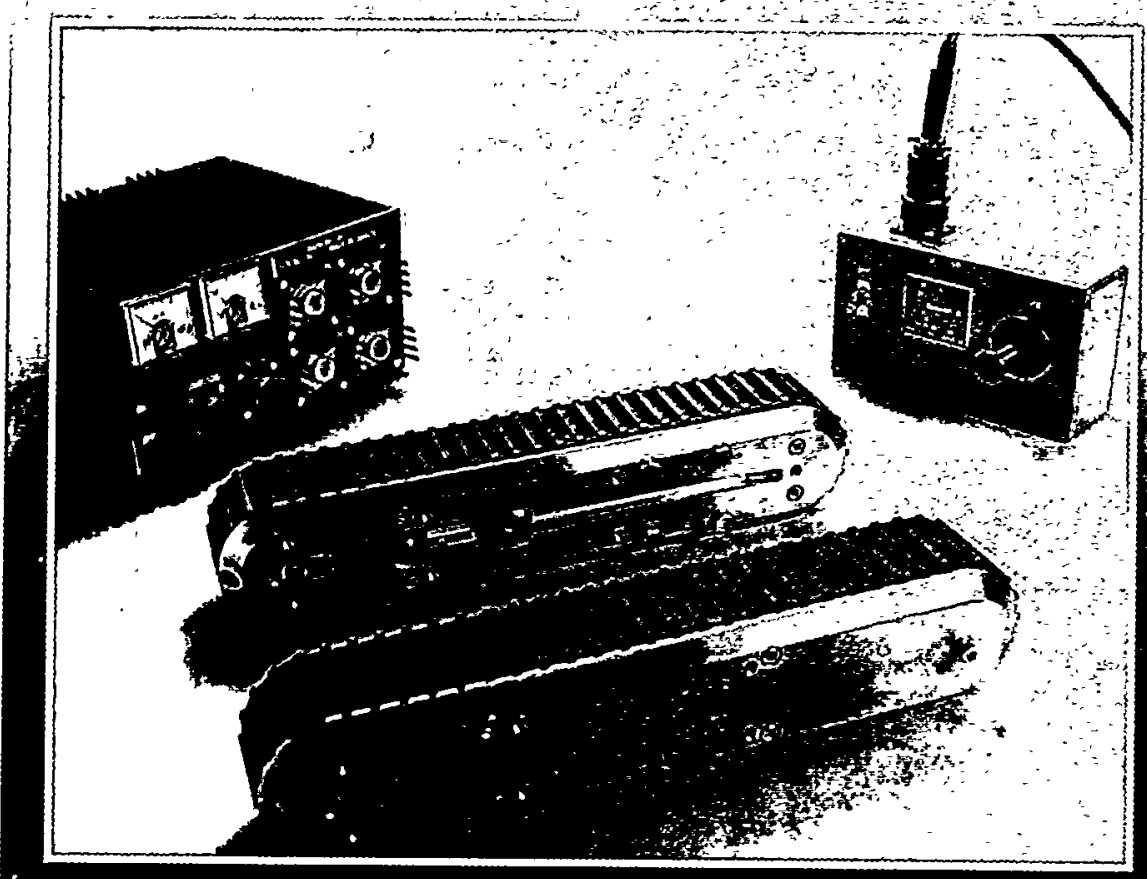

Left:

The Minitracs Power Supply and Control Units:

Bèlow:

Minitracs in a typical configuration for pipe inspection equipment

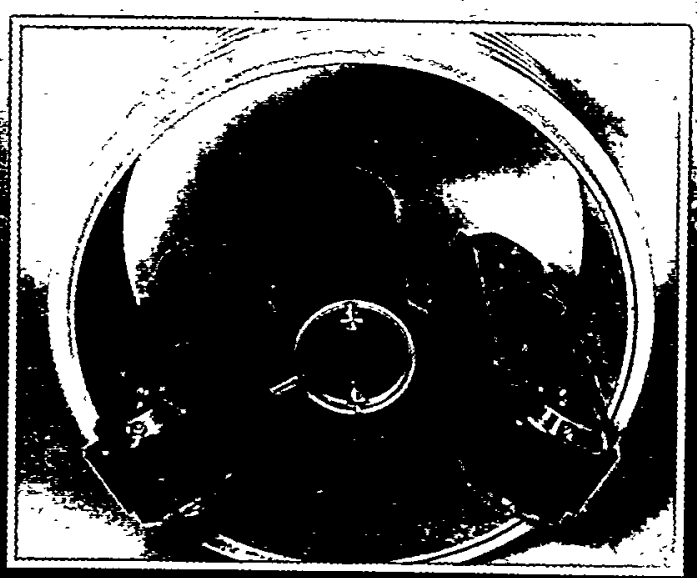

\section{Technical Specifications}

\section{MiniTrac}

Depth Rating: 0 - $100 \mathrm{ft} . / 30 \mathrm{~m}$

Speed: $0-35+$ feet $/ 10.5+m$ per minute depending on load

Pull Rating: $25 \mathrm{lbs} . / 11.5 \mathrm{~kg}$ per track

Dimensions: Height $-4 \mathrm{in.} / 10 \mathrm{~cm}$

Width - $3.5 \mathrm{in.} / 9 \mathrm{~cm}$ Length - $15 \mathrm{in.} / 38 \mathrm{~cm}$

Weight: Brass - $29 \mathrm{lbs} .113 \mathrm{~kg}$ ea

Aluminum - $14 \mathrm{lbs} .16 \mathrm{~kg}$ ea.

Operating Temp: $0.50^{\circ} \mathrm{C} / 32-122^{\circ} \mathrm{F}$

Operating Voltage: 24 VDC

Current: 4 amp per track at maximum load

Optional Equipment

Custom mounting brackets

Heavy lug track belts for rough terrain

MiniTracs Power Supply \& control systems $c / w$ tether cables

(to $1000 \mathrm{ft} . / 300 \mathrm{~m}$ length) and powered tether reels.

Custom design and fabrication of robotic vehicle chassis

Custom integration of MiniTracs power and control system with customer supplied instrumentation.

Continuing product development is vital to Inuktun. Inuktun reserves the right to alter any published specifications without notice.

\section{Authorized Representative:}

\section{IIUKUก}

- VefphThinh

Remotely operated pipe inspection system with unparalleled versatility.

- IIInITRARs

Powerful remotely operated crawler track transport system for a variety of instrumentation and tooling.

- millan VIJ

Remotely operated inspection system for confined spaces features the ability to chánge shape during operation.

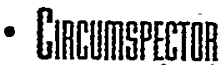

Versatile articulated camera for confined or difficult to access areas.

SRAllap Low-cost remotely operated camera equipped submersible

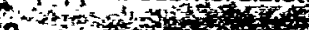

4fempt

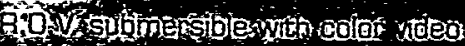
tospectioncamera
Inuktun Services tod. P.O. Box 99

Cedar, B.C. Canada VOR 1:10

Sales Office

Phone

[604] 722-2209 Fax

[604] 722-2031

\%10 00

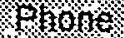

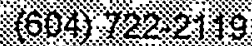

H.

$6014 \% 22.6$

Inuktun specializes: In the development Ff small, remotely operatèd vehicles z

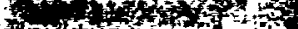
Mnuktun sañuit word neaning Senvice to Mankma 